\title{
Working
}

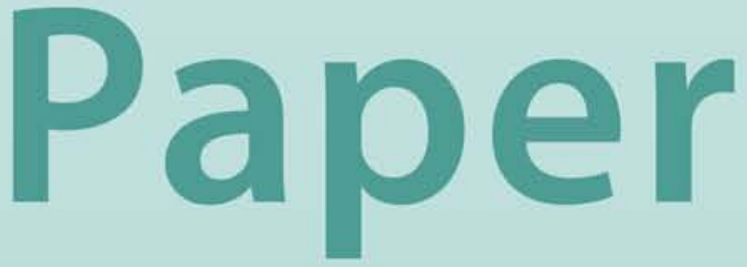




\title{
From Fixed to Float: \\ Operational Aspects of Moving Toward Exchange Rate Flexibility
}

\author{
Rupa Duttagupta, Gilda Fernandez, and \\ Cem Karacadag
}




\title{
IMF Working Paper
}

Monetary and Financial Systems Department

\section{From Fixed to Float: Operational Aspects of Moving Toward Exchange Rate Flexibility}

\author{
Prepared by Rupa Duttagupta, Gilda Fernandez, and Cem Karacadag ${ }^{1}$ \\ Authorized for distribution by Shogo Ishii
}

July 2004

\begin{abstract}
This Working Paper should not be reported as representing the views of the IMF. The views expressed in this Working Paper are those of the author(s) and do not necessarily represent those of the IMF or IMF policy. Working Papers describe research in progress by the author(s) and are published to elicit comments and to further debate.

This paper identifies the institutional and operational requisites for transitions to floating exchange rate regimes. In particular, it explores key issues underlying the transition, including developing a deep and liquid foreign exchange market, formulating intervention policies consistent with the new regime, establishing an alternative nominal anchor in the context of a new monetary policy framework, and building the capacity of market participants to manage exchange rate risks and of supervisory authorities to regulate and monitor them. It also assesses the factors that influence the pace of exit and the appropriate sequencing of exchange rate flexibility and capital account liberalization.

JEL Classification Numbers: F3, F31

Keywords: Exchange rate policy, foreign exchange markets, intervention, capital account Author’s E-Mail Address: rduttagupta@imf.org, gfernandez@imf.org, ckaracadag@imf.org

\footnotetext{
${ }^{1}$ We gratefully acknowledge Shogo Ishii for his strong support and guidance throughout this project and Inci Otker-Robe for proposing the topic of this paper and her contributions at its inception. Harald Anderson provided exceptional research assistance, and Kai Barvell, Mario Blejer, Jorge Canales-Kriljenko, and Adnan Mazarei provided valuable insights on individual country experiences. We also thank Roy Baban, Hervé Ferhani, Stefan Ingves, Matthew Jones, Christian Mulder, Barry Topf, participants in a IMF Monetary and Financial Systems Department seminar, reviewers from other departments within the IMF, and country authorities for their comments and suggestions.
} 


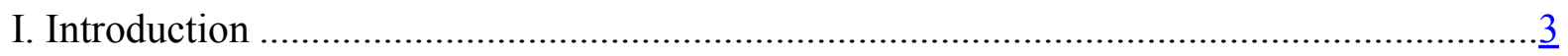

II. Institutional and Operational Requirements.......................................................

A. Foreign Exchange Market .........................................................................

B. Official Intervention in the Foreign Exchange Market ...................................... 11

C. Monetary Policy Framework and Nominal Anchor ........................................... $\frac{16}{22}$

D. Prudential Regulation and Management of Exchange Rate Risk ......................... 22

III. Pace of Exit to Exchange Rate Flexibility .............................................................25

IV. Exchange Rate Flexibility and Capital Account Liberalization ...................................29

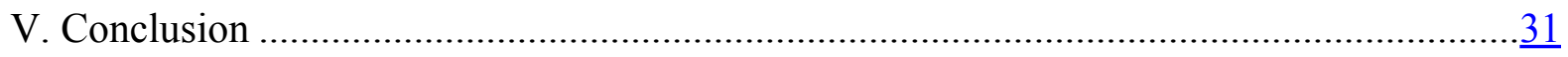

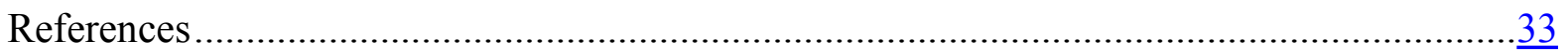

Figures

1. Exits by Type of Exchange Rate Regime, 1990-2002 ….............................................

2. Exchange Rate Regimes and Foreign Exchange Market Turnover for 1995, 1998, and 2001

3. Foreign Exchange Market Turnover in Emerging Market Countries ................................ 9

4. Preparing for an Orderly Exit from a Peg ................................................................28

5. Exchange Rate Volatility Under Disorderly Exits .................................................. $\frac{28}{30}$

6. Foreign Exchange Market Depth and External Openness …....................................... $\underline{30}$

Boxes

1. Orderly Versus Disorderly Exits to Flexible Exchange Rate Regimes ............................. 4

2. Experiences in Foreign Exchange Market Development................................................ 12

3. Experiences with Crawling Bands ..................................................................... $\frac{18}{21}$

4. Experiences with Moving to Inflation Targeting ...................................................... 


\section{INTRODUCTION}

The IMF's official de facto exchange rate regime classification shows that a majority of the Fund's member countries still maintain pegged exchange rate regimes (IMF, 2003). At the same time, a growing number of countries have adopted more flexible regimes over the past decade - most under market pressure (Box 1). Among the countries that voluntarily shifted to flexible regimes, the transitions have often been gradual.

The trend toward exchange rate flexibility is likely to continue for a variety of reasons. Rigid exchange rate regimes appear to be more crisis prone than flexible regimes. ${ }^{2}$ Some countries that do not implement sound macroeconomic policies will be forced to adopt more flexible regimes. Others will increase exchange rate flexibility to minimize the risks associated with economic and financial integration with the rest of the world. For example, expanding trade linkages requires greater exchange rate flexibility in response to external demand and terms of trade shocks. ${ }^{3}$ More recently, the upturn in capital flows to emerging market economies has put substantial upward pressure on exchange rates and complicated the conduct of monetary policy under pegs. Evidence also suggests that countries that have liberalized capital flows either adopt more flexible exchange rate regimes or generally are more susceptible to being forced off pegs (Eichengreen and others, 1999).

Moreover, as economies mature, the advantages of exchange rate flexibility appear to increase (Rogoff and others, 2003). Developing countries - particularly those with less exposure to short-term capital flows - may benefit from pegging their exchange rates to gain credibility and discipline fiscal and monetary policies. However, relatively developed emerging market economies with open capital accounts appear to gain from exchange rate flexibility. Rogoff and others (2003) thus argue that emerging market countries can benefit from investing in "learning to float," partly to overcome their "fear of floating."

${ }^{2}$ Bubula and Otker-Robe (2003) find that pegged regimes are more susceptible to currency crisis than floating regimes, while Rogoff and others (2003) find that the frequency of "twin" crises - where banking and currency crisis coincide - has been higher under more rigid exchange rate regimes, particularly for emerging markets during the 1990s.

${ }^{3}$ Duttagupta and Otker-Robe (2003) analyze the factors underlying exits from pegged spells in 34 countries during 1985-2002 and find that an increase in trade openness increases the probability of exiting to more flexible regimes. Broda and Tille (2003) analyze the effect of a decline in export prices in 75 developing countries and find that those with flexible exchange rate regimes experienced milder output contractions than those with fixed regimes. 


\section{Box 1. Orderly Versus Disorderly Exits to Flexible Exchange Rate Regimes}

The nature of exits from pegged regimes to more flexible regimes is analyzed using the IMF's de facto exchange regime database from 1990 to 2002 for all Fund member countries. The two main conclusions are (i) regardless of the methodology used, a large share of exits to flexible exchange rate regimes during 19902002 has been disorderly; and (ii) the pace of exit for orderly exits has been gradual. Despite the vulnerability of pegs to crisis, countries may be slow to adopt flexible regimes in the absence of the operational requisites to sustain them. Thus, a "checklist" of institutional requirements to support flexible regimes, provided in this paper, can help countries accomplish orderly transitions toward exchange rate flexibility.

Exits to flexible regimes are defined to include three categories of transitions: first, exits from all hard, fixed and crawling pegs to bands and floats; second, exits from bands to floats; and third, exits from managed floats to independent floats. Exits are considered only when the exited regime lasts for at least one year or if the country continues to increase its exchange rate flexibility during the same year (e.g., an exit from a fixed peg to a crawling band to a float). A total of 139 exits to flexible regimes are identified (Figure 1).

Figure 1. Exits by Type of Exchange Rate Regime, 1990-2002

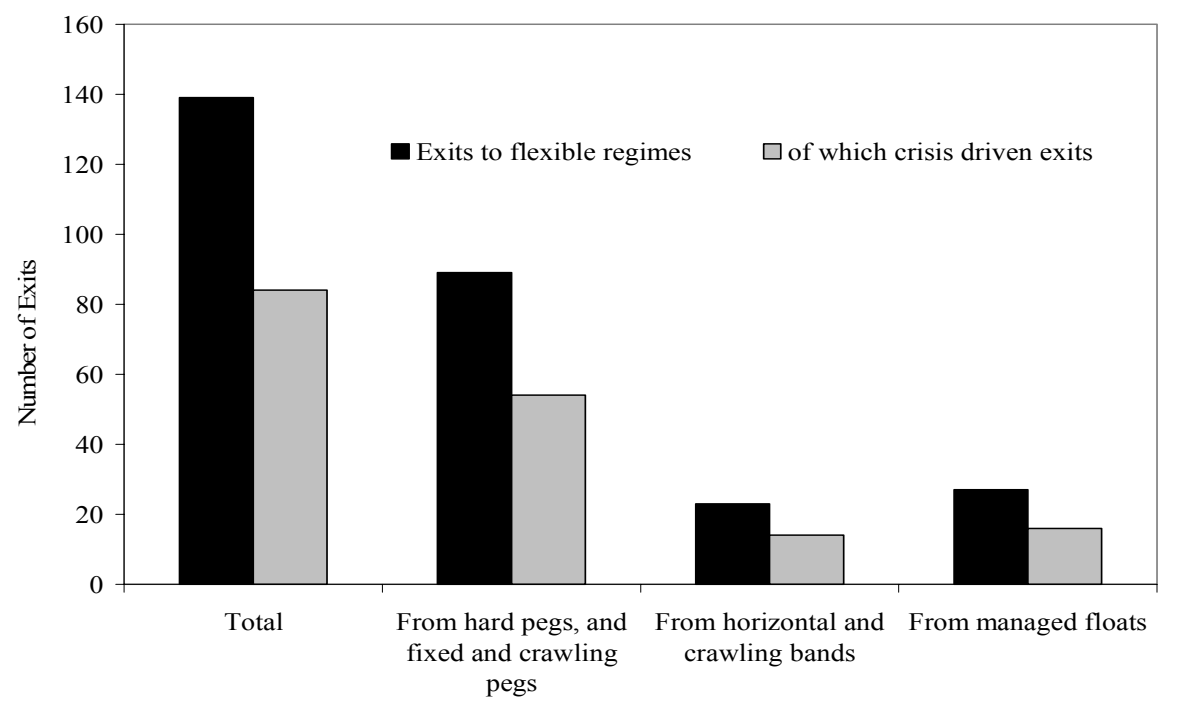

Two alternative measures are used to define a disorderly exit. The first measure uses the Asici and Wyplosz (2003) criterion, which identifies an exit when the depreciation rate of the nominal exchange rate over the period comprising six months before and six months after the exit is more than 25 percent. This measure identifies 77 disorderly exits, comprising about 55 percent of total exits. The second criterion defines a disorderly exit when the depreciation of the nominal exchange rate during the month after the exit is greater than or equal to the average depreciation over the previous six months plus two standard deviations of the depreciation rate over the same period. This identifies 84 disorderly exits comprising 60 percent of the total exits (shown in Figure 1).

Among the orderly exits to flexible regimes, only 39 percent characterized a one-step move from hard, fixed, or crawling pegs to floats, implying that many countries adopted a gradual approach toward exchange rate flexibility - e.g., Chile and Poland shifted from crawling pegs to crawling bands and gradually widened their crawling-band regimes over 14 years and 5 years, respectively, prior to adopting a floating regime. In fact, a few countries even opted to increase exchange rate flexibility within the same regime-e.g., Israel has gradually widened its crawling band to 55 percent by the end of 2003 . 
This paper provides an overview of the institutional, operational, and technical aspects of transitions to floats. In particular, it provides hands-on guidance to monetary authorities managing the transition as well as to multilateral financial institutions delivering technical assistance in these areas. It builds on previous work (Eichengreen and Masson, 1998, and Agénor, 2004) and draws on country experiences. Key issues that are addressed include the following:

- $\quad$ Developing a deep and liquid foreign exchange market;

- $\quad$ Formulating intervention policies consistent with the new exchange rate regime;

- $\quad$ Establishing an alternative nominal anchor in the context of a new monetary policy framework; and

- $\quad$ Building the capacity of market participants to manage exchange rate risks and of the supervisory authorities to regulate and monitor them.

The organization of the issues reflects the immediacy with which each may arise from an operational perspective. Moving off a fixed exchange rate first requires the presence of a market for pricing foreign exchange. Closely related is the central bank's role in that market, following the end of its price-setting interventions. The abandonment of the exchange rate as a nominal anchor creates possibly the biggest challenge from a macroeconomic policy perspective: namely, establishing a new nominal anchor and monetary policy framework, which require a long lead time in terms of preparation and execution. Exchange rate risk management and regulation also require considerable time to develop and ideally should be nurtured during exchange rate fixity to guard against unexpected exchange rate changes. However, the timing and priority accorded to each of the operational issues may vary from country to country, depending on initial conditions and economic structure.

The paper also explores the factors - the degree of operational preparedness and capital mobility - that influence the pace of exit and the sequencing of exchange rate flexibility and capital account liberalization. It discusses how the exit strategy can be designed to accomplish a smooth exit and limit the risks associated with capital mobility.

Sound macroeconomic and structural policies are necessary conditions for achieving orderly exits from pegs and for the smooth operation of any type of exchange rate regime, fixed or floating. Fiscal discipline and monetary policy credibility are critical to sustaining a fixed exchange rate regime and to avoiding misalignment under a floating regime. Similarly, a well regulated, supervised, and managed financial sector enhances policy flexibility and credibility by lowering the cost of potential interest and exchange rate movements and by strengthening monetary policy transmission. Furthermore, deep money markets with marketdetermined interest rates facilitate liquidity management under any exchange rate regime. They also help build a yield curve that can support the pricing of forward contracts under exchange rate flexibility. This paper does not elaborate on the macro and structural policies 
required to support exchange rate policies, given the vast literature in this area (Lindgren and others, 1996; Eichengreen and others, 1999; and Calvo and Mishkin, 2003).

The remainder of this paper is organized as follows. Section II discusses the institutional and operational requirements supporting an orderly transition, and, where possible, highlights the challenges central banks face in the aftermath of a forced exit. Section III discusses the pace of exit toward exchange rate flexibility. Section IV analyzes the sequencing of exchange rate flexibility and capital account liberalization. Section $\mathrm{V}$ concludes.

\section{INSTITUTIONAL AND OPERATIONAL REQUIREMENTS}

This section reviews the four key requirements of adopting a flexible exchange rate regime in an orderly manner. These include a liquid and efficient foreign exchange market, official foreign exchange intervention policies, an alternative monetary policy framework and nominal anchor, and the prudential regulation and institutional management of exchange rate risk.

\section{A. Foreign Exchange Market}

Operating a flexible exchange rate regime requires a sufficiently liquid and efficient foreign exchange market for price discovery. ${ }^{4} \mathrm{~A}$ well-functioning foreign exchange market allows the exchange rate to respond to market forces and minimizes instances and durations of excessive volatility and deviations from equilibrium. Sarr and Lybek (2002) characterize a liquid market as one with (i) relatively narrow bid-offer spreads to lower transaction costs (tightness), (ii) high turnover in volume as well as an abundance of orders to minimize the price impact of individual trades (depth and breadth); (iii) efficient trading, clearing, and settlement systems to facilitate the swift execution of orders (immediacy); and (iv) a wide range of active market participants to ensure that new orders flow quickly to correct order imbalances and misalignments (resiliency).

Foreign exchange markets of many developing countries lack depth and efficiency reflecting in part the extensive use of foreign exchange regulations (Canales-Kriljenko, 2003a; and Ho and McCauley, 2003). Markets exhibit a high degree of concentration, with only a few financial institutions controlling the bulk of foreign exchange transactions, even

\footnotetext{
${ }^{4}$ The foreign exchange market in general consists of a wholesale interbank market, where authorized dealers (usually banks and other financial institutions) trade among themselves, and a retail market where authorized dealers transact with final customers (usually households and firms). The interbank market, in particular, is where price discovery occurs through a decentralized allocation of foreign exchange by market participants on their own behalf as well as on behalf of their customers.
} 
when there are numerous institutions in the system. Interbank foreign exchange markets, when they exist, are relatively small compared to turnover at the bank-customer level, limiting the scope for price discovery. Foreign exchange regulations that constrain market depth include: (i) controls on cross-border capital flows that reduce market turnover; (ii) tight prudential limits on net open foreign exchange positions that temper market activity, particularly when expectations of exchange rate changes otherwise induce market participants to take bigger long or short positions; ${ }^{5}$ (iii) requirements to surrender foreign exchange receipts to the central bank under which the latter becomes a primary foreign exchange intermediary; and (iv) restrictions on interbank trading whereby dealers are only allowed to trade with customers and not among themselves (Canales-Kriljenko, 2003b).

Exchange rate rigidity itself may be a factor in foreign exchange market illiquidity. A central bank operating a fixed exchange rate regime is usually active in the market by necessity, which keeps market participants from gaining experience in price formation or exchange rate risk management and constrains interbank activity. Taken to its extreme, the central bank may dominate the interbank foreign exchange market and act as the primary foreign exchange intermediary. Market participants in a fixed exchange rate environment thus have less incentive to form views on exchange rate trends, take positions, or trade foreign exchange in light of the predetermined exchange rate level, which limits foreign exchange activity in both spot and forward markets. In particular, the explicit exchange rate guarantee provided by a peg obviates the need to actively manage foreign exchange positions and exchange rate risks. In addition, forward market activity is discouraged under a pegged exchange rate regime to reduce the scope of speculation against the local currency. The small size of the forward markets, in turn, limits opportunities for hedging.

Foreign exchange market depth under various exchange rate regimes provides evidence on the interdependence of foreign exchange market liquidity and exchange rate flexibility. An analysis of the foreign exchange market turnover across the spectrum of exchange rate regimes indicates a positive correlation between exchange rate flexibility and market depth in advanced economies, but not in developing ones (Figure 2). ${ }^{6}$ The lack of

\footnotetext{
${ }^{5}$ Dealers need to take open positions to provide liquidity to the market and absorb innovations in order flow, but this benefit is balanced against the need to contain prudential risks and prevent speculative activity. Canales-Kriljenko (2003a) and Abrams and Beato (1998) discuss country practices on open position limits.

${ }^{6}$ The analysis was based on data on foreign exchange market turnover for 42 countries for the years 1995, 1998, and 2001 from the Bank for International Settlements. The turnover data is available for the month of April only and was annualized for the purposes of the analysis. The results were robust to the following sensitivity analyses-(i) the exclusion of countries that adopted the euro from the sample of advanced economies to analyze any bias towards pegged regimes and (ii) the exclusion of the year 1998 to control for a period that was characterized by many emerging market crises.
} 
correlation between market turnover and exchange rate flexibility in developing countries may reflect a number of macroeconomic and institutional factors that are not controlled for in this simple correlation analysis, including the degree of economic and financial openness. For example, many developing countries may have thin foreign exchange markets even with floating regimes, which reflect the small size of the domestic financial sector and limited financial integration with the rest of the world.

Figure 2. Exchange Rate Regimes and Foreign Exchange Market Turnover for 1995,1998 , and 2001
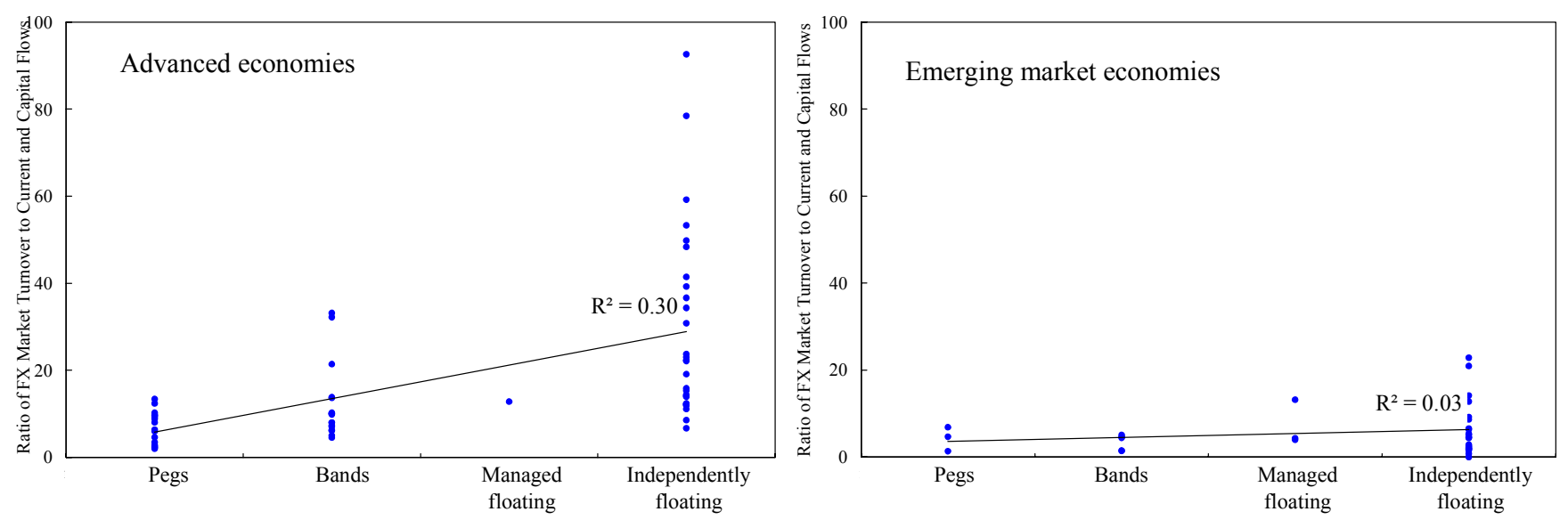

Sources: Bank for International Settlements; and International Monetary Fund.

In sum, at the time of their exit from pegs, most developing countries are likely to find themselves with a shallow foreign exchange market dominated by the monetary authorities. Moreover, upon exiting, market microstructure and expectations will assume paramount importance in the determination of the exchange rate. Against this background, the following steps can help improve the depth and efficiency of the market while allowing greater exchange rate flexibility. ${ }^{7}$

- Allowing some exchange rate flexibility — possibly within a band around a pegmay stimulate foreign exchange activity, which in turn, would help to operate a more flexible exchange rate regime in the future. A sense of two-way risk created by exchange rate variability would encourage market participants to take both short and long positions. For instance in Israel, under the exchange rate band, the intervention rate was allowed to vary from day to day to reflect market pressures. Then, the central bank organized daily market clearings on a multilateral basis, until the system was replaced by an interbank market where market participants traded among themselves bilaterally and the central bank entered the market only at its own initiative. In fact,

\footnotetext{
${ }^{7}$ These recommendations are based in part on Kovanen (1996).
} 
foreign exchange market turnover grew between 1998 and 2001 in emerging market countries that adopted more flexible exchange rate regimes, but declined (from an already lower base) in countries that adopted less flexible regimes or where regimes were unchanged (Figure 3).

Figure 3. Foreign Exchange Market Turnover in Emerging Market Countries

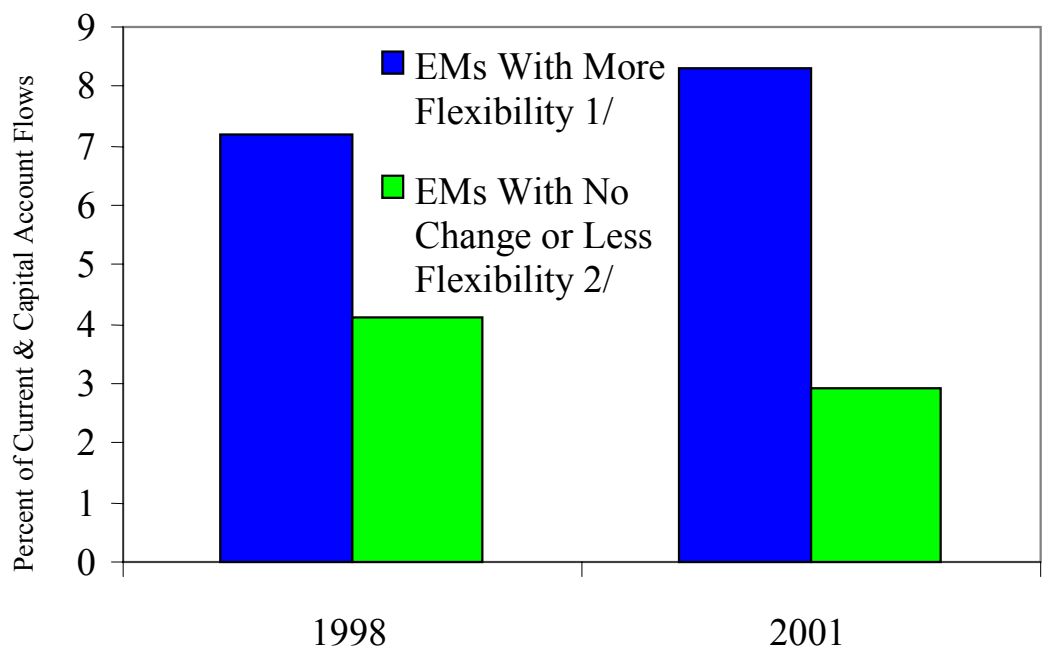

Sources: Bank for International Settlements and International Monetary Fund.

1/ Emerging markets with more flexibility include those that adopted more flexible exchange rate regimes since 1995, including Brazil, Chile, the Czech Republic, Philippines, Poland, Russia, South Africa, and Thailand.

2/ Emerging markets with no change or less flexibility include those that adopted less flexible exchange rate regimes since 1995 or whose regimes were unchanged, including Hungary, India, Malaysia, and Mexico.

- $\quad$ Reducing the central bank's market-making role, including its quotation of buying and selling rates, which undercut other market makers. The central bank should keep its trades with banks to a minimum (and generally not trade with non-financial customers at all), and it should be a price-taker when it enters the market.

- Increasing market information on the sources and uses of foreign exchange and on balance of payments trends (including information on individual categories under the current and capital accounts) as a basis for market participants to develop credible views on the exchange rate and future monetary policy, and efficiently price foreign exchange. Authorities should also ensure that information systems and trading platforms are capable of providing real-time bid and offer quotations in the interbank market. 
- Eliminating (or phasing out) regulations that stifle market activity. Some important measures would be: abolishing requirements to surrender foreign exchange receipts to the central bank (surrender requirements), taxes and surcharges on foreign exchange transactions, and restrictions on interbank trading, ${ }^{8}$ unifying segmented foreign exchange markets, and relaxing current and capital account restrictions to bolster the sources and uses of foreign exchange in the market. ${ }^{9}$ Easing capital controls, however, should be pursued gradually and only after the macroeconomic and institutional preconditions are largely in place (Ishii and others, 2002; and Karacadag and others, 2003). For example, financial institutions may need time to develop the capacity to intermediate funds prudently and manage the risks associated with volatile capital flows effectively. Moreover, significant progress should be made towards exchange rate flexibility before the capital account is fully liberalized (Section IV).

- Unifying and simplifying foreign exchange legislation and avoiding ad hoc and frequent changes to the law. Well-defined, simple and easily understood foreign exchange laws and regulations can improve market transparency and reduce the transaction costs of market participants, especially banks that are usually tasked with the implementation of the regulations. In addition, clearly defined regulations, transparent criteria and procedures for licensing dealers, and delegating exchange control authority to authorized dealers can help minimize the exercise of discretion or misinterpretation by market participants and enhance market transparency. Some countries have revised foreign exchange laws to improve the functioning of foreign exchange operations (e.g., Argentina in 2003, India in 1997, and Russia in 2004).

- $\quad$ Facilitating the development of risk-hedging instruments by lifting controls on forward market activity, once financial institutions achieve a certain level of sophistication in risk management and the supervisory authorities are capable of conducting risk-based supervision. However, some exchange rate flexibility may be desirable before full-scale forward market activity is allowed. The central banks of some advanced economies-Ireland (1980s), New Zealand (1980s), and Finland (1970s) — helped jump-start forward market activity by initially providing backup cover at officially quoted forward rates to commercial banks which enabled the latter to conduct forward sales and purchases and square their open positions (Quirk and

${ }^{8}$ Such restrictions may include outright bans on interbank trading or a requirement that all spot and forward market trades with customers have an underlying commercial transaction.

${ }^{9}$ Bulír (2004) finds for a sample of four transition countries - the Czech Republic, Hungary, Poland, and the Slovak Republic - that early liberalization of controls on foreign exchange market activity supported the operation of a flexible exchange rate regime by a faster than average adjustment of exchange rates to short-run deviations from the trend. 
others, 1988). ${ }^{10}$ In the mid-1980s, Chile authorized the operation of a forward market in conjunction with widening its crawling band regime, allowing commercial banks to trade foreign exchange options with maturities between 15 to 180 days with marketdetermined forward rates, which helped deepen the forward foreign exchange market.

The stabilization and development of the foreign exchange market become an especially daunting task when the exchange rate is floated under market pressure, and there is no time to prepare for the exit (Box 2). Under such circumstances, the authorities are generally faced with conflicting objectives with regard to their presence in the market: on the one hand, they need to sell foreign exchange to prevent excessive exchange rate depreciation; on the other hand, they have a strong interest in signaling that official intervention will not be geared to defend a particular exchange rate level. Country experiences with crisis-driven exits to floats underscore the need to signal the official commitment towards exchange rate flexibility, but also a readiness to resist disruptive exchange rate movements. Some common practices have been to gradually renounce the market making role of the central bank, tolerate exchange rate volatility, and maintain comprehensive surveillance of market transactions in order to detect and contain speculative activity.

\section{B. Official Intervention in the Foreign Exchange Market ${ }^{11}$}

The transition to a market-determined exchange rate creates the need to develop policies on the objectives, timing, and amounts of intervention. Under various forms of peg, official foreign currency purchases and sales are essentially rules based: the timing and amount of intervention - which must bridge the gap between foreign currency supply and demand at a given price - are predetermined. With exchange rate flexibility, intervention becomes discretionary, although authorities still can and do intervene for several reasons, including to correct misalignment, calm disorderly markets, accumulate reserves, and supply foreign exchange to the market.

\footnotetext{
${ }^{10}$ However, official guarantee of forward rates can impose large costs on the central bank, especially if it encourages speculative behavior. Thus, the central bank should contain its own foreign exchange exposure and limit the size of its forward operations. Indeed, central banks in Finland and Ireland withdrew from the foreign exchange market as early as 1980 and New Zealand in 1983 while progressively easing controls on forward activity.

11 This section draws on Canales-Kriljenko and others (2003) and Guimarães and Karacadag (2004).
} 


\section{Box 2. Experiences in Foreign Exchange Market Development}

The Argentine authorities faced the challenge of operating a floating exchange rate regime with minimal experience in intervention and no market information at the time of its crisisdriven exit from a currency board in January 2001. During the currency board era, the authorities did not collect data on market turnover and net open positions, and the central bank rarely intervened in the market, which lacked experienced dealers. Thus, upon floating, the authorities quickly established reporting requirements and net open position limits and required banks to submit two-way bids to the central bank three times a day. At the same time, the scarcity of foreign exchange, speculative activity, and unstable market conditions compelled the authorities to institute surrender requirements - first to the market, then to the central bank - and allow interbank trading only when it was supported by underlying customer orders

When Sri Lanka was forced off its crawling band to a floating regime in January 2001, the authorities temporarily adopted exchange controls to limit an overshooting of the exchange rate. These included: constraints on corporates' forward transactions with banks and on prepayment of bills, a reduction in banks' net open position limits, and very close scrutiny of the banks' activities to monitor speculative activity. However, while these measures helped to contain depreciation at the peak of market pressures, they were not conducive to the development of the foreign exchange market. Hence, over time the central bank phased out the controls, eased prudential limits on net open positions of banks, and revised its intervention guidelines to signal that intervention would take place to smooth extreme shortterm exchange rate volatility and build international reserves, and not to target the exchange rate level.

In Turkey, up until the disorderly exit from the crawling peg regime to a float in early 2001, the Central Bank of Turkey (CBT) historically had a dominant role in the foreign exchange market, being virtually the only market maker, quoting on all transactions and acting as counterparty in every transaction. Market participants had grown dependent on the central bank's constant presence and were unprepared to face market uncertainty. Under an IMFsupported stabilization program, the CBT gradually withdrew from the market, forcing market participants to trade among themselves. Particular measures were taken to signal the authorities' commitment towards the floating regime and encourage foreign exchange market activity. First, in mid-August 2001, the CBT issued a press release to emphasize that it would not target a particular exchange rate level. Second, the CBT became more tolerant to large fluctuations in the exchange rate without intervening. In fact, there have been long periods without any CBT intervention in the market and recent data suggests that the interbank foreign exchange market turnover is growing rapidly (Guimarães and Karacadag, 2004). Finally, the CBT stepped up its surveillance activity to gather detailed market information that would provide better knowledge about volatile market developments or speculative behavior. 
The potential disconnect between exchange rate levels and macroeconomic fundamentals creates a role for intervention under floating exchange rates. Marketdetermined exchange rates often deviate substantially from their "equilibrium values" implied by fundamentals in the short term, even in well-functioning foreign exchange markets. Like all other financial markets, foreign exchange markets are prone to various forms of failures - including herding and feedback trading - that can subject the exchange rate to unwarranted and serially correlated changes over time. As a result, central banks may have strong incentives to intervene in order to limit unwarranted exchange rate movements stemming from temporary shocks and to stabilize market expectations.

Correcting exchange rate misalignments, containing volatility, and calming disorderly markets are among the most common reasons for central bank intervention under flexible exchange rate regimes. Real exchange overvaluation can undermine export competitiveness and weaken the external position, while an undervalued exchange rate may create inflationary pressures. Even without misalignment, sharp exchange rate movements and volatility may be costly, particularly where policy credibility is weak. The exchange rate is often considered a symbolic and visible measure of the government's success in macroeconomic management, and may serve as a de facto nominal anchor for inflationary expectations for some time even after moving to a float. Moreover, erratic exchange rate movements and long-lasting misalignments can subject cost and income projections in the real sector to wide margins of error, inhibiting long-term planning and investment.

Exchange rate misalignments, however, are difficult to detect (Chinn and Meredith, 2001; Hinkel and Montiel, 1999; and Isard and others, 2001). There is no consensus on a methodology to estimate the equilibrium exchange rate. Frequently used indicators include the nominal and real effective exchange rates, productivity and other competitiveness measures, the terms of trade, the balance of payments, interest rate differentials, and parallel market exchange rates. However, these indicators do not usually allow policymakers to identify the degree of misalignment precisely enough to determine the appropriate timing and amount of intervention.

Detecting disorderly markets is equally challenging. Disorderly markets involve a collapse of liquidity, where market intermediaries face difficulties matching suppliers with end-users of foreign exchange. If market illiquidity persists, it can potentially have serious adverse effects on the real economy. Acceleration in exchange rate changes, widening bidoffer spreads, and a sharp increase in interbank trades relative to customer-bank turnover may indicate market illiquidity, where predominantly one-way customer orders are difficult to match. Trends in volatility, spreads, and turnover, however, can only be interpreted in the context of events, shocks, and news that may be driving them and the specific foreign exchange market in which they occur. Distinguishing disorderly markets from normal market dynamics is thus a difficult and subjective judgment call.

Even when the authorities detect exchange rate misalignment or destabilizing volatility, official intervention may not always be effective in containing them. The empirical evidence on the effectiveness of intervention in influencing the exchange rate is mixed, and 
even where favorable evidence is found, the impact of intervention on the exchange rate level is short-lived. Similarly, empirical studies find that intervention tends to increase, rather than decrease, exchange rate volatility, though this may be the desired effect to achieve a certain exchange rate level objective. ${ }^{12}$ Partly as a result, central banks in many advanced economies (e.g., Canada since 1998, Israel since 1997, New Zealand since 1985, and the United Kingdom since 1992) and in some emerging market economies (e.g., South Africa since 2000) seldom intervene in the foreign exchange market. ${ }^{13}$ Empirical analyses on intervention, however, need to be interpreted cautiously given the methodological problems in assessing the effectiveness of intervention.

To the extent that short-term exchange rate volatility occurs in an orderly (liquid) market, intervention may be unwarranted. Volatility often reflects the market process of price discovery, and several empirical studies have failed to detect measurable economic costs attributable to it. ${ }^{14}$ Moreover, volatility — within limits — induces market participants to learn to cope with and manage exchange rate risks. However, the central bank has reason to act when volatility reflects market illiquidity, heightens the risk of positive feedback trading, or threatens price stability. Under these circumstances, central bank intervention has the potential for jump-starting the market or tipping a perverse price trend in the reverse direction.

Thus in general, central banks should be selective in their interventions and parsimonious in their use of scarce foreign reserves. The challenge of detecting exchange rate misalignments and disorderly markets means that decisions on the timing and amount of intervention are highly subjective and may not always be worth "betting on." Moreover, intervention episodes should be relatively infrequent to maximize the element of surprise and

12 In developing economies, Guimarães and Karacadag (2004) find that intervention increases short-term volatility in Mexico, but decreases it in Turkey. For empirical studies on advanced economies, see references cited in Guimarães and Karacadag (2004), including Hung (1997), Dominguez (1998), Cheung and Chinn (1999), and Beine and others (2002).

${ }^{13}$ New Zealand recently modified its intervention policy to include possible intervention "for the purpose of influencing the level of the exchange rate to reduce exchange rate variability when the exchange rate is exceptionally and unjustifiably high or low..." (Reserve Bank of New Zealand (RBNZ), 2004a and 2004b). Nonetheless, the RBNZ is highly unlikely to intervene frequently in the future, if at all.

${ }^{14}$ Dominguez and Frankel (1993a) cite numerous studies in which the effect of exchange rate volatility on trade is small or nonexistent. More generally, the research surveyed in Rogoff (1999) indicates that the exchange rate regime and exchange rate volatility do not have detectable effects on output and trade. More recent studies on the small open economies of Ireland and New Zealand also find that exchange rate volatility has little or no impact on trade and investment (Bjorksten and Brook, 2002; and Bredin and others, 2002). 
the likelihood of effectiveness, and build market confidence in the official commitment to exchange rate flexibility. As investor confidence strengthens, policy pronouncements and the capacity to intervene (i.e., an adequate level of reserves) may suffice in most instances to achieve the desired change in the price trend, without an actual intervention operation.

Exercising restraint in central bank intervention can also help the authorities signal their commitment to a market-determined exchange rate. In particular, the central bank should refrain from intervening to target a predetermined exchange rate level or path unless a band regime is adopted. Importantly, interventions to smooth volatility should not be used as cover for targeting the exchange rate. Where a band is introduced as part of a gradual transition, intervention episodes may be more frequent, but the central bank should make full use of the exchange flexibility allowed by the bandwidth.

Transparency in intervention policies also helps build confidence in the new exchange rate regime, especially in the aftermath of forced exits. Many countries, among them the Philippines and Turkey, issued statements and published policy reports affirming their commitment to a market-determined exchange rate and that intervention would not be conducted to target a certain exchange rate level. Moreover, a public commitment to both the objectives of intervention and the criteria applied in its conduct enables market scrutiny of and accountability for the central bank's foreign exchange operations. The published intervention policies of Australia and Sweden are good examples of the type of policies that need to be developed and articulated to the market to enhance the effectiveness of official foreign exchange operations. ${ }^{15}$

Disclosing information on intervention with a time lag can also help market transparency and improve central bank accountability. For example, the United Kingdom has a policy of disclosing information on intervention (e.g., amount, date of, and reasons behind the intervention, and data on official foreign currency holdings) in a monthly press release. The European Central Bank (ECB) reports intervention episodes in a monthly bulletin, although the amounts are not disclosed. The U.S. Treasury typically confirms interventions on the same day of intervention, and provides more detailed information, e.g., amounts of intervention, in a quarterly report (Chiu, 2003).

Selected country experiences suggest that rules-based intervention may be useful when the exchange rate is not under significant downward pressure in a one-sided market. A rules-based intervention policy may help a country accumulate reserves or supply foreign exchange, without affecting the exchange rate. By design, rules-based policies usually involve preannouncing the timing and amount of interventions, and as such, are fully transparent. Establishing a track record in operating a flexible exchange rate regime with a rules-based intervention policy, in turn, may help central banks gain the experience and credibility to intervene on a more discretionary basis over time.

${ }^{15}$ See Rankin (2001) and Sveriges Riksbank (2002). 
Brazil, Mexico, and Turkey all implemented rules-based policies to signal their commitment to a market-determined exchange rate while achieving various other intervention objectives. Brazil's intervention policy ex ante limited the central bank's sales of foreign exchange to US\$50 million a day between July and December 2001. The policy was effective in filling the estimated balance of payments gap arising from a sharp reduction in capital inflows, without giving the impression that the central bank was targeting the exchange rate. In Turkey, foreign exchange sale and purchase auctions - whose timing and amount are determined and announced ex ante - have been an effective and transparent mechanism for reinforcing the central bank's commitment to a floating exchange rate regime, while helping to accumulate foreign exchange reserves. Similarly, Mexico's option-based intervention mechanism was effective in achieving the authorities' goal of accumulating reserves without affecting short-term exchange rate levels (Guimarães and Karacadag, 2004).

Over time, however, central banks may need flexibility in the conduct of foreign exchange operations to accommodate potentially volatile market conditions. Thus, the few countries that have implemented rules-based policies ultimately have abandoned or modified the rules to allow for discretion. For example, Canada's mechanical intervention policy of the 1990s was modified in 1995 and abandoned in 1998 to provide the central bank with greater discretion. Rules-based interventions were not effective in systematically affecting the level and volatility of the exchange rate because interventions lacked the element of surprise. Similarly, Brazil's rules-based intervention policy, which was revived in mid-2002, was subsequently relaxed in order to give the central bank more discretion over how, when, and by how much it could intervene in the spot market as it responded to changing market conditions.

International reserve management policies should also be reevaluated upon the transition to a more flexible exchange rate regime. On the one hand, the level of required reserves to maintain a flexible exchange rate may be less than the level needed to fix the exchange rate. Alternatively, reserves may be invested in longer-term assets with higher returns given the lower likelihood and frequency with which they may be used for intervention. On the other hand, a higher level of reserves may increase market confidence, increase the effectiveness of intervention and hence lower exchange rate volatility (Hviding and others, 2004).

\section{Monetary Policy Framework and Nominal Anchor}

Monetary control is the most important function of monetary policy in the immediate aftermath of exits from pegs, particularly when the exit is disorderly. Uncertainty over the level and volatility of the exchange rate under the new flexible regime inherently destabilizes expectations and sensitizes market participants to volatility. As a result, effective control of systemic liquidity is critical to avoiding the prospect of "too many local currencies chasing dollars," which in turn, can create a depreciation-inflation spiral. Whereas under exchange rate fixity, foreign exchange interventions serve as de facto liquidity management operations, the burden of liquidity management shifts to other instruments under exchange rate flexibility. Hence, while monetary policy instruments - including standing facilities, open 
market operations, and repurchase agreements - and liquid money markets are essential for managing systemic liquidity under any type of exchange rate regime, they are vital to sustaining monetary control under a flexible exchange rate regime.

In the longer term, country authorities must contend with the loss of the exchange rate as a nominal anchor. A pegged exchange rate usually serves as a nominal anchor for monetary policy, particularly in countries implementing exchange rate based stabilization programs. The exchange rate is an attractive nominal anchor because it is easy for the central bank to implement and for market participants to monitor and verify. Moreover, when the exchange rate pass-through to inflation is high, the exchange rate serves as a suitable nominal anchor for achieving price stability, particularly in open economies with weak institutional capacity and credibility.

Exiting a peg thus creates the need to replace the exchange rate with another nominal anchor and to redesign the monetary policy framework around the new anchor. The two tasks, in turn, require a substantial amount of capacity and credibility building, and thus planning ahead for the transition is critical to achieving an orderly exit. While countries can maintain flexible regimes without having a nominal anchor (e.g., the ECB, Switzerland, and the United States under independent floats, and Singapore under a managed float), the viability of this approach depends on the authorities' credibility to sustain a responsible monetary policy without a nominal anchor. Such credibility is generally difficult to build quickly, especially if a country had relied on a rigid exchange rate anchor until the exit. To preserve confidence in the monetary policy framework, an alternative nominal anchor would be desirable, particularly in countries with histories of high inflation.

The difficulty of developing a credible alternative nominal anchor to the exchange rate has caused many countries to relinquish its anchor role — and therefore fixity - only gradually. The prime example of this has been the use of a crawling band as an intermediate regime for transitioning to another nominal anchor, potentially over a long period. The band usually has been set symmetrically around a crawling central parity and gradually widened over time as the tension between the exchange rate and the inflation rate objectives was eventually resolved in favor of the latter. Chile, Hungary, Israel, and Poland successfully made the transition using crawling bands that were gradually widened in response to increases in capital inflows (Box 3). Lessons from their experiences include:

- $\quad$ The narrow scope for exchange rate flexibility in the early stages of the transition can constrain monetary policy independence and place the burden of aggregate demand management on fiscal and incomes policies. Hence, fiscal restraint and wage flexibility are essential to the credibility of the intermediate regime and to the successful transition to the new nominal anchor. 


\section{Box 3. Experiences with Crawling Bands}

Chile adopted a crawling peg in 1982 to mainly preserve external competitiveness rather than anchor inflationary expectations, i.e., the central parity was set to depreciate according to past inflation (Morande, 2001a and 2001b). During the 1980s, a band was introduced around the central parity, which was gradually widened to \pm 5 percent by 1989 . Strong capital inflows in the 1990 s, however, created tensions between the exchange rate and inflation objectives, which prompted the authorities to prioritize the latter. Thus, with the announcement of an explicit inflation target in 1990, achieving price stability became a priority. In particular, whenever there was a conflict between the inflation target and the exchange rate objective, the central bank acted in favor of the former (Schmidt-Hebbel and Werner, 2002; Morande, 2001a and 2001b; and Debelle, 2001). The prioritization of the inflation target helped to bolster public confidence in the authorities' proposed inflation objective despite operating a pegged exchange rate regime. Furthermore, starting from September 1998, the rate of crawl was revised to follow the expected future inflation rather than past inflation, which reflected a shift in the monetary policy approach to anchor inflationary expectations. The exchange rate was adjusted through a gradual widening of the crawling band regime - to \pm 10 in 1992 and \pm 12.5 percent in 1997, whereby greater exchange flexibility created strong incentives for developing forward and futures markets in foreign exchange. The availability of hedging instruments, in turn, contributed to a sharp decline in inflation pass through, which combined with the already low level of inflation achieved in 1999 (3 percent), led to the abandonment of the band in 1999 and the adoption of full-fledged inflation targeting in 2000. Analyses of Chile are unanimous in their emphasis on fiscal prudence as a key ingredient in the country's success in disinflation and transition to a new nominal anchor (Williamson, 1996, and Morande, 2001a and 2001b).

Hungary adopted a crawling peg (with \pm 2.25 percent band) in 1995 with the dual purpose of establishing a nominal anchor and maintaining external competitiveness (Varhegyi, 2001). The rate of crawl was based on the targeted (rather than realized) inflation rate. The risk of an overvaluation from inflation exceeding its target was minimized by a large initial devaluation. As in Poland, the authorities responded to upward exchange rate pressure generated by capital inflows with sterilized intervention, widening the band to \pm 15 percent, and adopting an inflation target in 2001. The higher exchange rate risk associated with the wider band deterred speculative flows and provided the necessary degree of monetary policy independence to effectively pursue price stability. Restraint in fiscal and incomes policies to temper aggregate demand, and productivity growth, were critical to the sustainability of the crawling peg, the success in disinflation, and the transition to inflation targeting.

Israel adopted a crawling band regime and began announcing inflation targets at the same time in late 1991 (Williamson, 1996). The band was first set at \pm 5 percent around the crawling parity and subsequently raised to \pm 7 percent in 1995 in response to strong capital inflows. The rate of crawl was set on a forward-looking basis to anchor inflationary expectations. From 1991 until 1996, the central bank maintained an inner, intramarginal, intervention band aimed at keeping the exchange rate close to central parity (Bufman and Leiderman, 2001). The inner band, however, led market participants to perceive minimal exchange rate risk and to shift to foreign currency borrowing. The abandonment of the inner band in 1996, with an asymmetric widening of the band to 28 percent in 1997 ( 21 percent in the upper limit and 7 percent in the lower limit), and the central bank's willingness to allow the shekel to depreciate markedly in 1998 heightened the perception of exchange rate risk and lowered the demand for foreign currency loans (Leiderman and Bufman, 1999).

Poland made the transition from a fixed exchange rate to inflation targeting during the 1990s (Kokoszczynski, 2001). In 1990, the exchange rate was fixed to the U.S. dollar as part of an exchange rate-based stabilization program. Concerns over real exchange rate overvaluation prompted the switch to a fixed peg against a basket of currencies in May 1991, followed soon after by a shift to a forward-looking crawling peg in October 1991 through mid-1995. Heavy capital inflows created tension between external and domestic price stability objectives however, leading the authorities to introduce $\mathrm{a} \pm 7$ percent band around the crawling parity to give monetary policy greater independence. The width of the band was gradually widened until it was abandoned in 2000 , but even before then the inflation target had become the nominal anchor under the inflation targeting framework adopted in 1998. 
- $\quad$ Restricting exchange rate movements within a narrower intervention band relative to the publicly announced bandwidth can create the perception of an implicit exchange rate guarantee and reduce the sensitivity of market participants to exchange rate risks. Two-way exchange rate movements are necessary to give participants an incentive to develop hedging instruments and manage exchange rate risks.

- In the context of maintaining two nominal anchors-i.e., the exchange rate and the inflation target - public confidence in the commitment towards the latter can be bolstered by conveying clearly the priority of price stability in the event of a conflict between the two objectives. In fact, all four countries were able to subordinate the exchange rate objective to the inflation target — either explicitly or implicitly — while maintaining crawling band regimes.

Many countries moving to flexible exchange rate regimes have favored an inflation targeting framework over money targeting, reflecting a broad consensus on an inflation target being a more reliable and effective nominal anchor (Khan, 2003). While money targeting can serve as an alternative nominal anchor after exiting a peg, the weak relationship between monetary aggregates and inflation limits the effectiveness of money targets. The instability of demand for money causes many countries to target monetary aggregates only indicatively, and instead, use short-term interest rates as operational targets. ${ }^{16}$ Short-term interest rates have the advantage of signaling and transmitting monetary policies more effectively given the higher frequency and greater ease with which they can be monitored. Inflation targets have emerged as the most viable alternative to the exchange rate to perform the role of nominal anchor.

Countries that have managed orderly exits from pegs thus have generally adopted inflation targeting over long time horizons. The lengthy transition periods have reflected in part the time required to fulfill the necessary institutional requirements and macroeconomic conditions including: (i) a central bank mandate to pursue an explicit, publicly announced inflation target as the overriding objective of monetary policy; (ii) central bank operational independence and accountability; (iii) transparency in the conduct and evaluation of monetary policy actions that promotes accountability; (iv) a reliable methodology for forecasting inflation; (v) a forward-looking operating procedure which systematically incorporates forecasts into policy actions and responds to deviations from targets; and (vi) a supportive fiscal policy and a well regulated, supervised, and managed financial sector (Eichengreen and others, 1999; Mishkin, 2003; Carare and others, 2002; and Fraga and others, 2003).

${ }^{16}$ When dollarization is high, the relationship between monetary aggregates and prices is even weaker and depends on the nature of dollarization. For example, dollarization in the form of currency substitution would imply that dollar monetary assets are used for transactions, and thus should be included as part of a monetary target, while asset substitution would imply that it is not (see Baliño and others, 1999). 
Even when countries were forced off a peg, they have often adopted inflation targeting gradually (Box 4, note that Brazil was a rare exception). The authorities used the time to tighten monetary policies and signal their commitment to price stability. Thus, prior to adopting inflation targeting, both Korea and Thailand stabilized prices under the post crisis IMF-supported programs that were based on ceilings on the central bank's net domestic assets. Also, since its crisis driven exit to a floating regime in 2003, Uruguay has adopted base money targeting within an interim framework prior to adopting inflation targeting. Mexico followed the same strategy during 1995-2000.

The macroeconomic requirements of inflation targeting, including the lack of fiscal dominance and financial system stability, have led some to question its appropriateness for developing countries. Thus, public finances have to be strong enough to ensure the government does not rely on seignorage for deficit financing and the financial sector is robust enough to withstand anti-inflationary monetary policies, including high real interest rates. Inflation should already be largely under control, at most in low double-digits (Eichengreen and others, 1999).

Regardless of whether preconditions for full-fledged inflation targeting are met, many of its elements are critical to building a reliable monetary policy framework. Thus, whatever type of monetary policy regime that is adopted, it should accord uncontested priority to price stability over competing objectives, provide operational independence to the central bank, establish transparency and accountability for the conduct of monetary policy, and demonstrate a capacity to forecast inflation and produce policy actions consistent with maintaining price stability. Where one or more of these elements are absent, monetary authorities would stand to benefit from developing them. In this regard, the popularity of inflation targeting reflects a general consensus on the desirability of a nominal anchor and its embodiment of best practices in monetary policy formulation and implementation.

Even when its basic preconditions are met, inflation targeting is more complicated to operate in developing economies that are open and exposed to potential trade and capital account shocks. Pass-through to inflation from the exchange rate is also higher because of histories of high inflation and weak central bank credibility, which raise market uncertainty over the commitment to the inflation target (Eichengreen, 2002; and Ho and McCauley, 2003). Developing economies thus face the challenge of managing higher volatilities of inflation, the exchange rate, output, and interest rates, with relatively weaker institutional credibility, compared to advanced economies (Fraga and others, 2003).

The more difficult operating environment heightens the challenge of building credibility. Unanticipated shocks and macroeconomic volatility make it harder to forecast inflation accurately and increase the incidence of deviations from targets (Eichengreen, 2002; and Fraga and others, 2003). The higher frequency of shocks and target "misses", in turn, obscure official policy objectives and actions, impairing policy credibility. The absence of long-term financial markets and instruments in most emerging economies, moreover, places the burden of monetary policy transmission on short-term interest rates. Thus, monetary authorities must react more quickly and frequently to forecasted deviations from targets. 


\section{Box 4. Experiences with Moving to Inflation Targeting}

Brazil adopted inflation targeting relatively soon after the crisis-driven exit from the crawling peg in January 1999. The relative ease in transition was facilitated in part by the central bank's already high degree of operational independence (Central Bank of Brazil, 1999). However, since inflation targeting was adopted in 1999, Brazil has had to manage the financial shocks and exchange rate volatility associated with Argentina's financial crisis. In their comprehensive survey of Brazil's experience with inflation targeting, Minella and others (2003) emphasize the importance of central bank actions consistent with the inflation target and high levels of transparency and communication with the public. The authors emphasize that one of the main tasks of the central bank has been to build public confidence in its commitment towards price stability. For this, the authorities invested in improving public communication through informal speeches, publishing minutes of the monetary committee meetings on a weekly basis, and publishing an inflation report on a quarterly basis. Thus, despite having breached inflation targets during 2001-02, the authorities were successful in containing inflation expectations by communicating clearly to the public the reasons for missing the inflation targets (mainly due to unanticipated shocks). Monetary policy consistency and transparency has paid off in other ways too: the degree of inflation persistence, pass-through, and volatilities in inflation, the exchange rate, and output, have declined since the adoption of inflation targeting.

Mexico adopted inflation targeting gradually. Upon a crisis-driven exit from its exchange rate band to a float at end-1994, the central bank announced its intention to adopt full-fledged inflation targeting. However, the next five years were used to restore credibility in the authorities' policy agenda by reducing fiscal dominance and increasing transparency in the monetary policy framework. Soon after the adoption of the floating exchange rate regime, the central bank first adopted a monetary growth target that implied a ceiling on the net domestic assets. Within this monetary targeting regime, the authorities were able to achieve impressive disinflation - the rate of inflation declined from over 35 percent in 1995 to less than 10 percent in 2000. The relevance of an inflation target over a monetary base target increased over time. Starting 2000, the central bank started publishing its quarterly inflation reports that provided a candid analysis of inflation prospects, the conduct of monetary policy and the impending risks for future inflation (Schmidt-Hebbel and Werner, 2002). Formal inflation targeting was adopted in January 2001. However, the authorities continue to use a measure of money, corto, as an operating target and have not yet linked the inflation target to a shortterm operating target such as the overnight interest rate.

The Philippine authorities decided to move towards inflation targeting in early 2000, but actual implementation took place in January 2002. The interim period was used to stabilize the economy after the 1997 currency crisis, make technical preparations for working with the new framework, and communicate and educate the public about impending changes in the monetary policy framework (Kongsamut, 2001). Progress was also made in consolidating macroeconomic policies, which helped reduce inflation from about 10 percent in 1998 to $4 \frac{1}{2}$ percent in 2000. Inflation targeting was perceived as more reliable compared to base money targeting that was subject to instability in the demand for money (Debelle and Lim, 1998), and exchange rate targeting, which was subject to speculative attacks. To increase public awareness of the shift in the monetary policy framework, the central bank (BSP) explained the nuances of inflation targeting in its website and through regular briefings. In particular, it stressed that its commitment towards price stability would not be compromised by other objectives, such as financing the fiscal deficit and having an exchange rate target. The inflation target is set jointly by the government and the BSP, which has served to bolster the government's own responsibility to help achieve the inflation target. 
Against this background, Eichengreen (2002) and Fraga and others (2003) underscore the importance of communication and transparency and the central bank's decision-making process in building credibility and successfully implementing inflation targeting. Inflation targeting will have more credibility when it is anchored in an intermediate targeting rule based on inflation forecasting and in a formal process of monetary policy making (as opposed to an informal or "ad hoc" decision-making process). A high level of transparency and communication with the public can help monetary authorities explain their assessment of inflationary trends and policy actions. Transparency and communication can also help the market decipher the central bank's reaction function. A credible reaction function, in turn, can enhance the anchor role of the inflation target.

\section{Prudential Regulation and Management of Exchange Rate Risk}

Determining the scale and scope of exchange rate risk exposures in the financial and nonfinancial sectors is another key area for countries planning an orderly exit from pegs. Exchange rate risk exposures can have an important bearing on the pace of exit, the type of flexible exchange rate regime adopted (e.g., band versus float), and official intervention policies. While exchange rate risk is present under pegged regimes, its regulation and management become more pressing under flexible regimes, where exchange rates fluctuate on a daily basis. Even when these risks are modest early on, market participants need to develop the capacity to measure and monitor them to avoid a build-up of exposures over time.

Containing exchange rate risks across all sectors of the economy is critical to a successful transition to exchange rate flexibility. In particular, the analysis and management of exchange rate risks need to be comprehensive and focus on the balance sheets of all sectors of the economy including the public, financial, and nonfinancial sectors (Allen and others, 2002). Exchange rate risk analysis and management are particularly important in economies where the share of foreign currency assets and liabilities in balance sheets is high.

Evaluating exchange rate risk exposures, in turn, involves detailed balance sheet analysis - focusing not only on currency compositions of balance sheet items, but also the maturity, liquidity, and credit quality of foreign currency assets and liabilities. The Mexican financial crisis in 1994 demonstrated how poor foreign currency liquidity management by the government can trigger a currency crisis. Similarly, the East Asian crisis showed how unhedged foreign exchange borrowing by the corporate sector can translate into massive losses for creditor banks and a surge in demand for foreign currency. Even when foreign currency liabilities and assets are matched, the use of short-term foreign currency funds to finance foreign currency loans to unhedged corporations or households causes exchange rate risk of borrowers to translate into sizable credit risks for banks.

The management of exchange rate risk is composed of four elements: information systems, measurements of exchange rate risk, internal risk policies and procedures, and prudential supervision. 
First priority should be accorded to establishing the information systems required to monitor various sources of exchange rate risk, including the sources of foreign currency funds used for domestic credit expansion and lending in foreign currency (Delgado and others, 2002). This requires formal reporting requirements that specify the reporting format and frequency, and in some instances, the definition and methodology for measuring foreign exchange risk. Data reflecting indirect exchange rate risk exposures of banks to large borrowers should also be closely monitored through regular surveys of corporate sector exposures or by requiring the borrowers to provide information on their foreign currency incomes, other foreign debts and hedging operations. Information on remaining rather than original maturities of foreign currency liabilities is more useful (Hawkins and Turner, 2000). Accounting rules and procedures must also ensure that the values of asset and liabilities are reflected accurately and on a timely (continuous) basis.

The second key element is to design formulas and analytical techniques to measure exchange rate risk. Traditional accounting measures of the overall foreign currency position include the gross aggregate position (the sum of all net short and all net long positions), the net aggregate position (the absolute value of all short positions less all long positions) and the short-hand position (the greater of the sum of short positions and the sum of long positions). ${ }^{17}$ All open position calculations should include net spot and forward positions, guarantees, and net future income/expenses not yet accrued, but already fully hedged. Accounting measures of exchange rate risk, however, have important drawbacks - they do not fully account for the correlation in currency movements or the relative size of variations (e.g., stable versus volatile) between currencies which result in open positions, and they treat currency risk as being independent from other risks, which is usually not the case (Abrams and Beato, 1998). Thus, more forward-looking risk management techniques should be built after embracing exchange rate flexibility, including value-at-risk models (e.g., using the historical simulation or Monte Carlo approach) as well as stress testing (see Blaschke and others, 2001 and references therein). The measurement of exchange rate risks may either be based on institutions' internal models or on standard systems prescribed by the supervisory authorities. ${ }^{18}$ Greater foreign participation in the financial system, especially by internationally active foreign banks, can help raise access of the domestic market participants to technical expertise and improved practices in risk management.

17 The Basel Committee recommends a capital charge of 8 percent on the open position based on the short-hand method and recommends that the net open position does not exceed 2 percent of capital, although countries with greater risk exposures may need to adopt more conservative limits (Basel Committee of Banking Supervision, 1998).

${ }^{18}$ For instance, the United States requires banks to use internal models; in Australia, Bahrain, Canada, Czech Republic, Malta, Netherlands, Slovenia, and Switzerland, banks have the option of using internal models with the central bank's approval or the standardized approach. 
The third building block of exchange rate risk management is internal risk policies and procedures. These may include, among other things, setting internal limits on concentration in foreign currency loans, allocating specific provisions for the additional credit risks associated with foreign currency lending, and analyzing the potential impact of exchange rate movements on foreign currency borrowers. (Delgado and others, 2002). Establishing strong internal controls - including a written policy on foreign exchange operations, exposure limits, risk management procedures, and a system of monitoring compliance where front and back offices are fully separated - is also critical (Abrams and Beato, 1998). Moreover, institutions should adopt good corporate governance standards, including regular monitoring, review and approval of risk policies and procedures by the board of directors to maintain appropriate checks and balances within the institution. In addition, banks could also encourage their clients to hedge against exchange rate risks. ${ }^{19}$

Internal risk management systems need to be complemented by the prudential regulation and supervision of foreign exchange risk. Prudential measures may include limits on net open positions (as a percent of capital), foreign currency lending (as a percent of foreign currency liabilities), and overseas borrowing and bond issuance (as a percent of capital). Other forms of prudential measures include limits on the range of foreign exchange operations banks are allowed to perform through licensing requirements, capital requirements against foreign exchange risk, and the issuance of regulations or guidelines on the design of banks' internal control systems.

Prudential measures vary widely across countries. Many countries impose limits on overall foreign exchange positions. For example, in a sample of 41 countries (from the IMF's Banking Supervision Database), 23 impose limits on overall positions and 13 on single currency positions, 14 have capital requirements, and 13 have other types of measures. In this sample, overall open position limits range from 10 to 60 percent of bank capital. Some countries like Argentina and India require banks to use the value-at-risk method in measuring exchange rate risk, while other countries such as the United States require banks to establish their own foreign currency position limits.

Supervisors should be vigilant against foreign currency exposures of financial institutions - particularly of foreign currency lending to sectors that do not generate foreign currency revenues or are exposed to volatile returns (e.g., property sector). Supervisors in some countries adopt prudential controls such as tighter reserve requirements on banks for foreign currency deposits relative to domestic currency deposits (e.g., Israel, Russia), minimum credit-ratings requirements for external borrowing by domestic corporations (e.g., Chile in the 1990s), and asymmetric open position limits (e.g., Malaysia in 1994). To ensure

${ }^{19}$ In Hungary, banks have encouraged their clients through promotion campaigns to hedge exchange rate risks. As a result, the practice of hedging has slowly increased (IMF, 2002). However, Desruelle and others (2004) argue that dynamic hedges on a yearly basis do not fully reduce balance sheet risks and should be complemented by having natural hedges. 
that regulations are effective, supervisors should improve their enforcement capacity in effectively implementing regulations and ensuring greater compliance. Also, supervisors should go beyond the checklist approach of monitoring compliance with prudential ratios and develop a risk-based supervisory system with a more proactive approach to ensure that the supervisee's internal control systems are adequate and properly enforced.

\section{Pace of Exit to Exchange Rate Flexibility}

This section discusses the relative merits of a gradual versus rapid pace of exit to a float. Gradualism involves moving towards a free float in measured steps, for example, by shifting from a fixed peg against a single currency to a fixed or crawling peg against a basket and further to an exchange rate band with incremental increases in bandwidth. By contrast, a rapid approach involves relatively fewer intermediate steps, if any. The choice of new regime depends on the factors driving the exit, including external competitiveness, increased integration with world financial markets, and monetary policy independence. The pace of the transition also reflects the adequacy of the institutional underpinnings for operating a flexible exchange rate and the openness of the capital account.

Moving from a single currency to a basket currency peg can be an important first step towards exchange rate flexibility. Pegging to a basket of currencies has the advantage of reducing the transmission of external shocks to the domestic economy and tempering the exchange rate's exposure to potentially erratic movements of a single currency anchor. The basket may comprise a weighted average of the currencies of a country's main trading partners, with the weights reflecting their relative importance in trade or financial flows. A shift to a crawling peg regime against a basket of currencies can help preserve external competitiveness in the presence of a persistent inflation differential between domestic inflation and that of the trading partners. Adopting variants of pegged regimes rather than moving to a float in one step also has the advantage of being operationally easier to maintain than wide exchange rate bands and floats. However, they continue to constrain monetary policy and can be difficult to sustain under capital mobility.

Moving to an exchange rate band - horizontal or crawling - can provide greater exchange rate flexibility and monetary policy independence. This can be achieved by introducing a band around the existing (central) parity or by adjusting the exchange rate level and then introducing a band around the new parity. To the extent that the exchange rate is under continuous upward or downward pressure, adjusting the level first may be necessary to ensure that the flexibility provided by the bandwidth is not quickly exhausted by a potential misalignment. The width of the band will reflect the trade-off between the costs of exchange rate volatility and the benefits of monetary policy independence.

Under any exit strategy, each step forward should ensure two-way risk in exchange rate movements. For example, when a band is used, the band should be wide enough to ensure that the exchange rate moves in both directions around the central parity and creates the perception of exchange rate risk. A move to a narrow band under persistent upward 
pressures can result in the exchange rate hitting the upper limit of the band, forcing the monetary authorities to either defend the band or widen the bandwidth further. Frequent revisions in bandwidth, in turn, can impair market credibility and induce speculative pressures to test the band limits. These issues become more pressing with greater capital account openness. To address the disadvantages associated with gradualism, the Bank of Israel broke away from the previous trend of restrained increases in the bandwidth of the crawling band (about 2-3 percent increase in every step during 1989-1995) by widening the band from \pm 7 percent to a total of 28 percent in June 1997 (Frenkel, 1997).

A gradual exit strategy is appropriate if the foreign exchange market is relatively undeveloped. This approach may help reduce the risks of excessive exchange rate volatility after the exit and deepen the foreign exchange market given the mutually reinforcing relationship between exchange rate flexibility and foreign exchange activity (e.g., Chile, and Israel until 1997). Even if a gradual pace is adopted, some exchange rate flexibility should be allowed relatively early to stimulate the foreign exchange market. However, some countries exited in one-step from fixed pegs to floats by taking advantage of improved foreign exchange inflows over a sustained period and relying on increased market liquidity to augment foreign exchange operations and deepen the market. For example, Bangladesh and Sudan in mid-2003 exited from fixed pegs to managed floats against a background of sustained current and capital account inflows that boosted foreign exchange liquidity.

The absence of full-fledged inflation targeting should not preclude a rapid exit strategy, provided that there is a robust commitment towards price stability. The building blocks of inflation targeting - such as fiscal discipline, operational independence of the monetary authorities to pursue low inflation, credible steps to contain inflationary pressures, and transparency and accountability - are fundamental to the success of any monetary policy regime regardless of whether inflation targeting is formally adopted. Indeed, some countries floated their currencies relatively quickly and maintained sound monetary policies, while fulfilling the preconditions for inflation targeting. For example, South Africa exited from a fixed peg to a float in the early 1980s, but formally adopted inflation targeting in 2000. Others, which were forced to float in one step, used monetary targeting as an interim strategy prior to adopting inflation targeting (Box 4). Moreover, if monetary policy independence is the underlying motivation behind the exit, a quick pace toward exchange rate flexibility would support this objective. Some countries, faced with heavy capital inflows under pegs, accelerated the pace of exit to enhance monetary policy flexibility against inflationary pressures (Box 3 and Williamson, 1996).

The market's exposure to foreign exchange exposures and capacity to monitor and manage exchange rate risk are key determinants of the pace of exit. Risk identification and management systems, and prudential regulation of these risks, help minimize market vulnerability to potentially large exchange rate movements. However, if foreign exchange exposures are low, capacity building need not delay a gradual increase in exchange rate flexibility. A flexible exchange rate itself can help increase market awareness of exchange rate risks and better prepare for exchange rate flexibility. For example, Israel increased the bandwidth of its crawling band regime in an asymmetric fashion in mid-1997, which 
increased the market's perception of downward exchange rate risk and contained their foreign exchange exposures (Bufman and Leiderman, 2001).

Thus, there are clear trade-offs involved in choosing a rapid versus gradual approach to moving towards exchange rate flexibility. A rapid approach-if undertaken from a position of macroeconomic strength and a generally prudent monetary policy - can signal the commitment towards greater exchange rate flexibility more credibly relative to a gradual approach. Moving in fewer steps to a float also provides greater discretion on foreign exchange intervention; the lack of commitment to defend a predetermined exchange rate path or bandwidth allows the central bank to limit its interventions and conserve its potentially limited foreign exchange reserves. Nonetheless, in the absence of the supporting institutional framework (e.g., deep foreign exchange market and comprehensive foreign exchange risk management), a rapid strategy increases the risk of excessive exchange rate volatility and its potentially adverse effects on inflationary expectations and market credibility.

Early preparation for an exchange rate float can bolster the chances of success of the exit strategy - gradual or rapid. Many of the operational areas require substantial time to build and the groundwork should be laid under the peg. Figure 4 provides an illustration of how the preparation for a transition can be phased. ${ }^{20}$ Several aspects of the operational prerequisites - including securing central bank independence, improving inflation forecasting capacity and monetary policy transparency, developing information systems on foreign exchange risk, and increasing information on balance of payments developments - can be undertaken early on, even before exiting a peg. The second stage may involve allowing some exchange rate flexibility to stimulate foreign exchange market activity, and continuing to develop other operational areas. Intervention policies can be addressed at a relatively later stage, once greater exchange rate flexibility is embraced.

While the pace of exit is not a matter of choice under disorderly exits, the authorities still need to prioritize among the operational requisites to manage the flexible regime. In this regard, stabilizing the exchange rate is usually the top priority, given the extremely high level of volatility following the exit, particularly in emerging market economies (Figure 5). Stabilizing the exchange rate, in turn, often hinges on eliminating the dollar shortage in the market and maintaining monetary control by avoiding massive liquidity support for the financial system (Berg and others, 2003). Efforts should also be made to signal a conservative monetary policy stance, although the explicit design of an alternative nominal anchor would probably take more time.

${ }^{20}$ This sequencing is meant to be illustrative to emphasize the benefits of advanced preparation while recognizing that coordination of the pace of exit with development of the operational tools would depend on country specific circumstances. 
Figure 4. Preparing for an Orderly Exit from a Peg

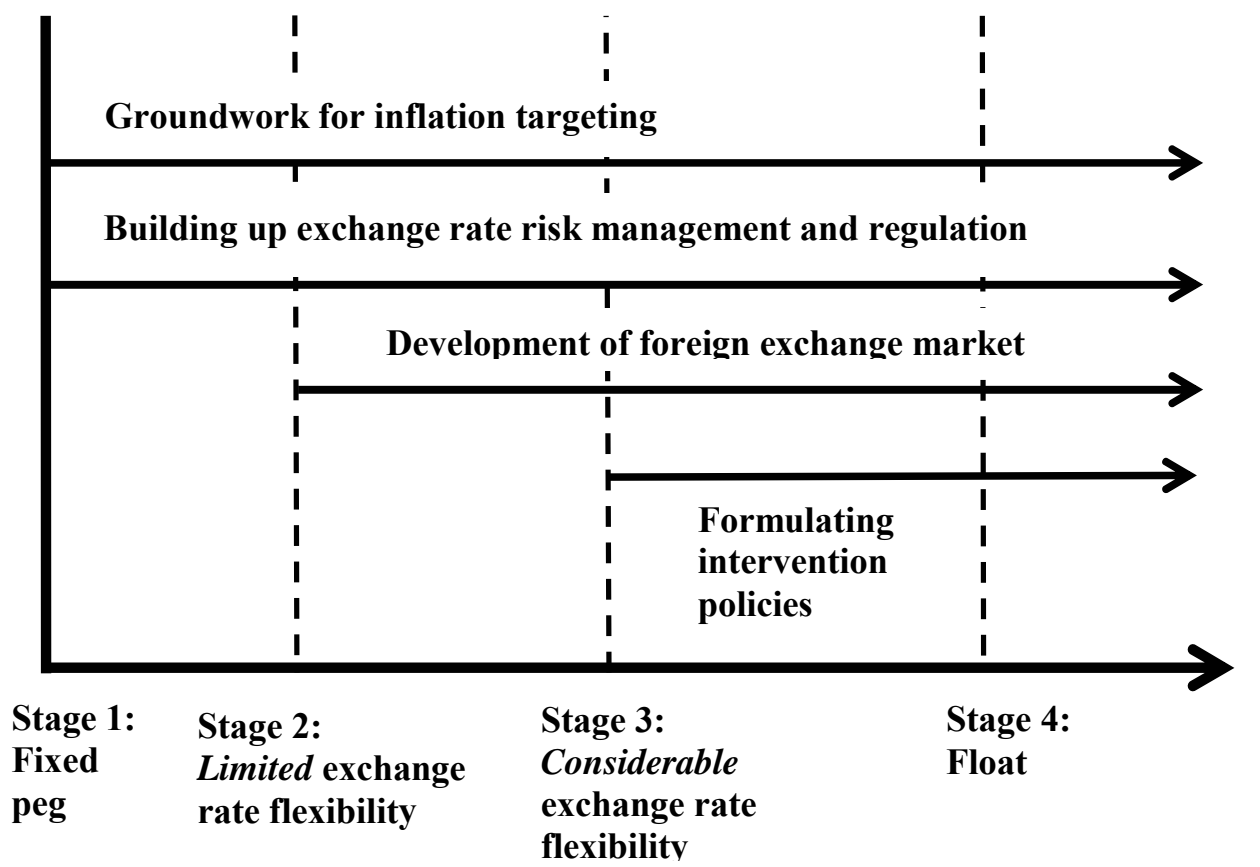

Full-

fledged inflation targeting

Figure 5. Exchange Rate Volatility Under Disorderly Exits

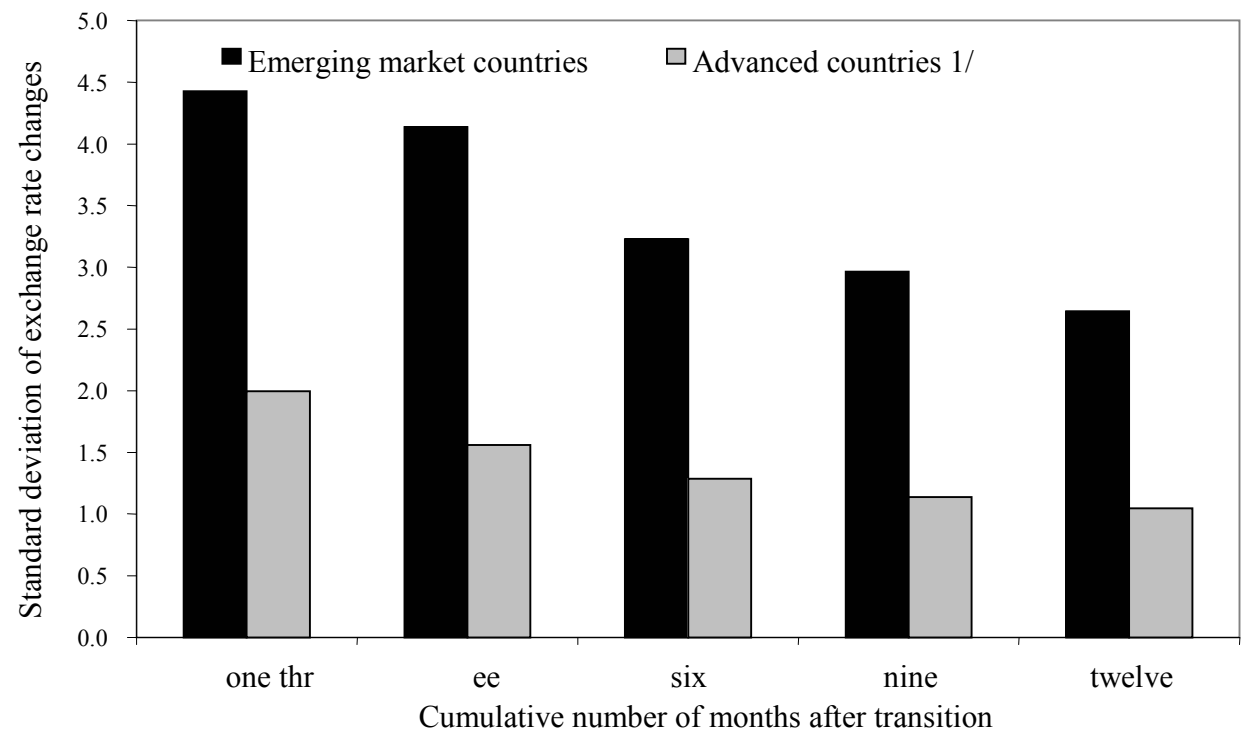

Source: Datastream.

1/ Figure based on a sample of 11 emerging market countries (Argentina, Brazil, the Czech Republic, Egypt, India, Indonesia, Mexico, Russia, Thailand, Turkey, and Uruguay), and 5 industrial countri es (Greece, Iceland, Italy, Finland, and Sweden). Standard deviations are based on daily exchange rate changes. 


\section{Exchange Rate FleXibility and Capital ACCount Liberalization}

This section explores the sequencing of exchange rate flexibility and full-blown capital account liberalization, and the trade-offs involved in pursuing one before the other. Introducing exchange rate flexibility before capital account liberalization has the advantage of enabling the economy to absorb capital account shocks at a lower cost to the real economy than would be possible under exchange rate fixity. By contrast, liberalizing the capital account can expand the sources and uses of foreign exchange and deepen the foreign exchange market, which is essential to operating a flexible exchange rate. The extent to which the capital account is liberalized asymmetrically-more open to inflows than outflows or vice versa - also affects the risks and trade-offs involved in the sequencing of exchange rate flexibility and capital account liberalization.

The emerging market experiences over the last decade highlight the risks of opening the capital account before adopting a flexible exchange rate. Many countries were forced off pegs after sudden reversals of capital flows under open capital accounts (e.g., Mexico in end1994, Thailand in July 1997, and Brazil in early-1999). Others faced heavy inflows and upward pressure on pegged rates and had to allow exchange rate flexibility to avoid overheating the economy (e.g., Chile and Poland during the 1990s). Thus, even under favorable economic conditions, opening the capital account before introducing exchange rate flexibility can destabilize domestic liquidity conditions, create macroeconomic imbalances, and precipitate speculative attacks.

More recent empirical evidence confirms the risks associated with premature capital account liberalization. For example, Bubula and Otker-Robe (2003) find that pegged regimes are more prone to crises than floats, especially for countries that are exposed to capital flows. This highlights the two well-known advantages of adopting a flexible exchange rate regime before dismantling capital controls. First, a flexible exchange rate can mitigate the real effects of potentially volatile financial flows, and second, exchange rate flexibility can deter speculative inflows by creating a perception of currency risk.

An open capital account is not a necessary precondition for deepening the foreign exchange market. Arguably, the elimination of exchange controls on current account transactions could also bolster the foreign exchange market without embracing the risks associated with cross-border capital mobility. Moreover, the potential positive impact of capital account liberalization on foreign exchange market depth is not observed in the data. A simple correlation analysis of market turnover and financial flows for a sample of 42 countries reveals only a weak relationship of market depth with capital account openness, and somewhat surprisingly, also a weak relationship with current account openness 
(Figure 6). ${ }^{21}$ These results strengthen the case for prioritizing exchange rate flexibility over full capital account liberalization. ${ }^{22}$

Figure 6. Foreign Exchange Market Depth and External Openness
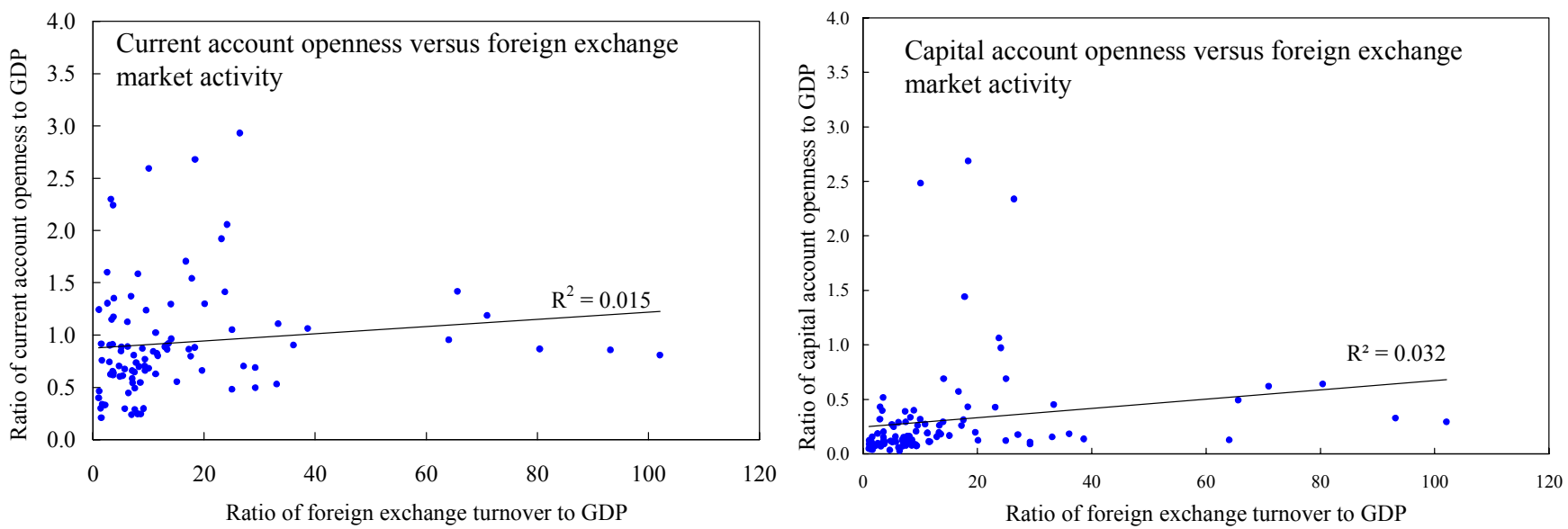

Sources: Bank for International Settlements and International Financial Statistics, IMF.

Notes: Current account openness is defined as the sum of trade and factor flows and transfers in both directions, expressed as a ratio of GDP. Capital account openness is defined as the sum of all capital flows in both directions plus errors and omissions, expressed as a ratio of GDP. Foreign exchange activity is defined as the total turnover in the foreign exchange market, expressed as a ratio of GDP.

Even when exchange rate flexibility takes precedence, the direction and composition of capital account liberalization has macroeconomic risk implications. For instance, opening the capital account to inflows runs the risk of creating excess liquidity and credit growth. More fundamentally, a substantial asymmetry in the openness of the capital account can introduce an upward (or downward) bias in the value of the exchange rate relative to its longterm equilibrium value. ${ }^{23}$ Thus, the transition towards exchange rate flexibility should be supported by gradually removing existing asymmetries in the openness of the capital account to facilitate an orderly correction of any potential misalignment in the exchange rate.

${ }^{21}$ Note that a more thorough regression analysis would be required to address whether foreign exchange activity depends on capital account openness after controlling for current account openness, which is not done here.

${ }^{22}$ The successful liberalization of the capital account itself depends on a wide range of issues related to the economy, financial sector stability and reform, and sequencing issues, which are explored in detail in Ishii and others (2002).

${ }^{23}$ For example, because China is relatively more open to capital inflows than outflows, some observers have speculated that the present upward pressures on the renminbi may not continue if capital outflows were allowed (Lau, 2003, and Greenspan, 2004). 


\section{Conclusion}

This paper identifies the operational issues involved in moving from pegged exchange rate regimes to more flexible regimes. Four areas of institutional support are highlighted as being particularly important, including the need to develop an efficient and liquid foreign exchange market, formulate credible foreign exchange intervention policies, establish a new nominal anchor and monetary policy framework, and build the capacity to manage and regulate exchange rate risk. In addition, the paper analyzes the pace of exit, and the sequencing of exchange rate flexibility and capital account liberalization.

Enhancing the efficiency and liquidity of the foreign exchange market hinges on minimizing impediments to market making and to price discovery. To this end, the authorities can take one or more of the following steps: liberalize foreign exchange controls that constrain market activity, increase market information, and rationalize foreign exchange related legislation. Moreover, some exchange rate flexibility-e.g., within a band around a peg-would also help reinforce market development.

The stabilization and development of the foreign exchange market becomes an especially challenging task when the exchange rate is floated under duress, with little time for advance preparation. Under these circumstances, priority should be accorded to gradually renouncing the market-making role of the central bank, allowing reasonable exchange rate volatility to signal a commitment to the floating regime, and maintaining comprehensive surveillance of market transactions in order to detect and contain excessive speculative activity.

Upon exiting a peg, foreign exchange intervention should be designed to credibly signal the commitment to a market-determined exchange rate. Thus, central banks should be selective in their interventions and parsimonious in their use of foreign reserves. Transparency in intervention policies - including a public commitment to a marketdetermined exchange rate and disclosure in intervention operations - also helps build market confidence. Selected country experiences suggest that rules-based intervention may be useful when the exchange rate is not under significant downward pressure in a one-sided market.

Exiting a peg creates the need for a new nominal anchor and monetary policy framework, both of which involve lengthy processes. Preparations for an alternative nominal anchor such as inflation targeting - including reforms in the central bank law, improving monetary policy transparency, and communication with the public - can be made under the peg. If the authorities adopt an inflation target in the context of an exchange rate band, it is important to signal the priority of the inflation target over any exchange rate objective.

Containing exchange rate exposures in all sectors of the economy is critical to a successful transition to a flexible regime. Even if exposures are modest, market participants need to develop the capacity to monitor and measure risks associated with daily exchange rate movements. The management and regulation of exchange rate risk require efforts in four areas. First, information systems required to monitor the sources of exchange rate risk should 
be established. The second key element is to design formulas and analytical techniques to measure exchange rate risk. The third is internal risk policies and procedures within financial institutions. Finally, risk management techniques and systems need to be complemented by prudential regulation and supervision of exchange rate risks.

The pace of exit depends on the state of development of the operational pillars needed for managing a flexible regime. A one-step approach - if undertaken from a position of macroeconomic strength and a generally prudent monetary policy - can more credibly signal the move toward greater exchange rate flexibility. In the absence of the supporting institutional framework, however, this strategy raises the risk of excessive exchange rate volatility and its potentially adverse effects on market confidence and inflationary expectations. Conversely, gradualism allows the time to build the operational areas to support the float. Even with a gradual pace, however, each step forward should allow enough exchange rate flexibility to increase two-way risk in exchange rate movements. Allowing too little flexibility — such as a narrow band around a peg-without correcting for potential misalignments in the exchange rate level may cause the exchange rate to quickly move to the top (bottom) of the band because of appreciation (depreciation) pressures, forcing the authorities to manage a de facto "revalued" ("devalued") peg.

Exchange rate flexibility should precede full-fledged capital account liberalization. A flexible exchange rate can mitigate the real effects of potentially volatile financial flows and deter speculative inflows by creating a perception of currency risk. Even when exchange rate flexibility takes precedence, the direction and composition of capital account liberalization has macroeconomic risk implications. A substantial asymmetry in the openness of the capital account can introduce an upward (or downward) bias in the value of exchange rate relative to its long-term equilibrium value. Thus, the move toward exchange rate flexibility should be supported by gradually reducing existing asymmetries in the openness of the capital account to facilitate an orderly correction of any potential misalignment in the exchange rate.

Finally, even before exiting a peg, policymakers can and should begin laying the groundwork for operating a flexible exchange rate. Some operational areas, particularly the institutional framework for inflation targeting, take substantial time to fully develop, and work on them should therefore start early. Exchange rate risk management and regulation are vital even under a pegged regime and should be on a strong footing prior to further advancement in risk management techniques under exchange rate flexibility. Other areas, such as the development of the foreign exchange market, can be jump-started by allowing limited exchange rate flexibility early in the preparation phase. Such advance preparation would facilitate a smooth exit even when a country is forced to adopt a relatively rapid pace of exit owing to cross-border financial flows. 


\section{REFERENCES}

Abrams, Richard K., and Paulina Beato, 1998, "The Prudential Regulation and Management of Foreign Exchange Risk," IMF Working Paper 98/37 (Washington: International Monetary Fund).

Agénor, Pierre, 2004, “Orderly Exits from Adjustable Pegs and Exchange Rate Bands: Policy Issues and Role of Capital Flows," Global Development Finance 2004 Report Background Study (Washington: World Bank).

Allen, Mark, Christoph Rosenberg, Christian Keller, Brad Setser, and Nouriel Roubini, 2002, "A Balance Sheet Approach to Financial Crisis," IMF Working Paper 02/210 (Washington: International Monetary Fund).

Asici, Ahmet, and Charles Wyplosz, 2003, “The Art of Gracefully Exiting a Peg," The Economic and Social Review, Vol. 34, No. 3, pp. 211-28.

Baliño, Tomas J.T., Adam Bennett, and Eduardo Borensztein (1999), Monetary Policy in Dollarized Economies, IMF Occasional Paper No. 171 (Washington: International Monetary Fund).

Basel Committee on Banking Supervision, 1998, Amendment to the Capital Accord to Incorporate Market Risks (Basel: Bank for International Settlements).

Beine, Michel, Agnes Benassy-Quere, and Christelle Lecourt, 2002, “Central Bank Intervention and Foreign Exchange Rates: New Evidence from FIGARCH Estimations," Journal of International Money and Finance, Vol. 21, pp. 115-44.

Berg, Andrew G., Christopher J. Jarvis, Mark R. Stone, and Alessandro Zanello, 2003, "ReEstablishing Credible Nominal Anchors After a Financial Crisis: A Review of Recent Experience," IMF Working Paper 03/76 (Washington: International Monetary Fund).

Bjorksten, Nils, and Anne-Marie Brook, 2002, "Exchange Rate Strategies for Small Open Developed Economies Such As New Zealand," Reserve Bank of New Zealand Bulletin, March 2002, Vol. 65, No. 1.

Blaschke, Winfrid, Matthew T. Jones, Giovanni Majnoni, and Soledad Martinez Peria, "Stress Testing of Financial Systems: An Overview of Issues, Methodologies, and FSAP Experiences," IMF Working Paper 01/88 (Washington: International Monetary Fund).

Bredin, Don, Stilianos Fountas, and Eithne Murphy, 2002, “An Empirical Analysis of ShortRun and Long-Run Irish Exports: Does Exchange Rate Volatility Matter?” Central Bank of Ireland Technical Paper 01/RT/02. 
Broda, Christian, and Cedric Tille, 2003, "Coping with Terms-of-Trade Shocks in Developing Countries," Current Issues in Economics and Finance, Vol. 9, No. 11 (New York: Federal Reserve Bank of New York).

Bubula, Andrea, and Inci Otker-Robe, 2003, "Are Pegged and Intermediate Exchange Rate Regimes More Crisis Prone?” IMF Working Paper 03/223 (Washington: International Monetary Fund).

Bufman, G., and L. Leiderman, 2001, "Surprises on Israel's Road to Exchange Rate Flexibility," paper presented during the IMF High Level Seminar on Exchange Rate Regimes: Hard Peg or Free Floating?, IMF, March 19-20, 2001.

Buliřr, Ales, 2004, "Liberalized Markets Have More Stable Exchange Rates: Short-Run Evidence from Four Transition Countries,” IMF Working Paper 04/35 (Washington: International Monetary Fund).

Calvo, Guillermo, and Frederic Mishkin, 2003, "The Mirage of Exchange Rate Regimes for Emerging Market Countries,” NBER Working Paper No. 9808 (Cambridge, Massachusetts: National Bureau of Economic Research).

Canales-Kriljenko, Jorge, 2003a, "Foreign Exchange Market Organization in Selected Developing and Transition Economies: Evidence from a Survey," IMF Working Paper 03/95 (Washington: International Monetary Fund).

, 2003b, "Foreign Exchange Intervention in Developing and Transition Economies: Results of a Survey," IMF Working Paper 03/95 (Washington: International Monetary Fund).

, Roberto Guimarães, and Cem Karacadag, 2003, "Official Intervention in the Foreign Exchange Market: Elements of Best Practice,” IMF Working Paper 03/152 (Washington: International Monetary Fund).

Carare, A., Andrea Schaechter, Mark. R. Stone, and Mark D. Zelmer, 2002, "Establishing Initial Conditions in Support of Inflation Targeting," IMF Working Paper 02/102 (Washington: International Monetary Fund).

Central Bank of Brazil (Research Dept), 1999, "Issues in the Adoption of an Inflation Targeting Framework in Brazil."

Cheung, Yin-Wong, and Menzie Chinn, 1999, "Macroeconomic Implications of the Beliefs and Behavior of Foreign Exchange Traders," unpublished, University of California, Santa Cruz.

Chinn, Menzie, and G. Meredith, 2001, “Testing Uncovered Interest Parity at Short and Long Horizons," revision of NBER Working Paper No. 6797. 
Chiu, Priscilla, 2003, "Transparency versus Constructive Ambiguity in Foreign Exchange Intervention,” BIS Working Paper, 144 (Basel: Bank for International Settlements).

Debelle, G., 2001, “The Case for Inflation Targeting in East Asian Countries,” Reserve Bank of Australia Annual Conference Volume.

— Framework for the Philippines," IMF Working Paper 98/39 (Washington: International Monetary Fund).

Delgado, Fernando L., Daniel S. Kanda, Greta Mitchell Casselle, and R. Armando Morales, 2002, "Domestic Lending in Foreign Currency," in Building Strong Banks Through Surveillance and Resolution (Washington: International Monetary Fund).

Desruelle, Dominique, Nicholas Blancher, Christian Mulder and Serguie Dodzin, 2004, "Liquidity Management," forthcoming as an IMF Working Paper (Washington: International Monetary Fund).

Dominguez, Kathryn, 1998, "Central Bank Intervention and Exchange Rate Volatility," Journal of International Money and Finance, Vol. 17, 161-90. , and Jeffrey Frankel, 1993a, Does Foreign Exchange Intervention Work? (Washington: Institute for International Economics).

Duttagupta, Rupa, and Inci Otker-Robe, 2003, "Exits from Pegs: An Empirical Analysis," IMF Working Paper 03/147 (Washington: International Monetary Fund).

Eichengreen, Barry, 2002, “Can Emerging Markets Float? Should They Inflation Target?” (Berkeley: University of California, Berkeley).

—_, and Paul Masson, 1998, Exit Strategies Policy Options for Countries Seeking Greater Exchange Rate Flexibility, IMF Occasional Paper No. 168 (Washington: International Monetary Fund).

—- Miguel Savastano, and Sunil Sharma, 1999, "Transition Strategies and Nominal Anchors on the Road to Greater Exchange Rate Flexibility," Essays in International Finance No. 213 (New Jersey: Princeton University).

Fraga, Arminio, Ilan Goldfajn, and Andre Minella, 2003, "Inflation Targeting in Emerging Market Economies," Banco Central do Brasil Working Paper Series, No. 76 (Brasilia: Banco Central do Brasil). 
Frenkel, Jacob, 1997, "Speech on Stability and Exchange Rate Policy," speech at a meeting of the Japan Society of Microeconomics in Japan, May 1997.

(http://www.bankisrael.gov.il/publeng/publeslf.php? misg $i d=13 \&$ year $=1997$ )

Greenspan, Alan, 2004, "Current Account," speech before the Economic Club in New York. http://www.federalreserve.gov/boarddocs/speeches/2004/20040302/default.htm

Guimarães, Roberto, and Cem Karacadag, 2004, “The Empirics of Foreign Exchange Intervention," IMF Working Paper 04/123 (Washington: International Monetary Fund).

Hawkins, John, and Philip Turner, 2000, "Managing Foreign Debt and Liquidity Risks in Emerging Economies: an Overview," Bank for International Settlements Policy Papers, No. 8, pp. 3-59 (Basel: Bank for International Settlements).

Hinkle, Lawrence, and Peter Montiel, 1999, Exchange Rate Misalignment: Concepts and Measurement for Developing Countries (Washington: World Bank).

Ho, Corrinen, and Robert N. McCauley, 2003, "Living with Flexible Exchange Rates: Issues and Recent Experience in Inflation Targeting Emerging Market Economies," BIS Working Paper No. 130 (Basel: Bank for International Settlements).

Hung, Juan, 1997, "Intervention Strategies and Exchange Rate Volatility: a Noise Trading Perspective," Journal of International Money and Finance, Vol. 6, pp. 779-93.

Hviding, Ketil, Michael Nowak, and Luca A. Ricci, 2004, “Can Higher Reserves Help Reduce Exchange Rate Volatility?" forthcoming as an IMF Working Paper (Washington: International Monetary Fund).

International Monetary Fund, 2002, "Hungary_Financial System Stability Assessment Follow-up,” IMF Country Report No. 02/112 (Washington: International Monetary Fund).

_ 2003, "Exchange Arrangements and Foreign Exchange Markets: Developments and Issues," World Economic and Financial Surveys (Washington: International Monetary Fund).

Isard, Peter, Hamid Faruqee, G. R. Kincaid, and Martin J. Fetherston, 2001, Methodology for Current Account and Exchange Rate Assessments, IMF Occasional Paper No. 209 (Washington: International Monetary Fund).

Ishii, Shogo, Karl Habermeier, Jorge Ivan Canales-Kriljenko, Bernard Laurens, John Leimone, and Judit Vadasz, 2002, Capital Account Liberalization and Financial Sector Stability, IMF Occasional Paper No. 211 (Washington: International Monetary Fund). 
Karacadag, Cem, V. Sundararajan, and Jennifer Elliott, 2003, "Managing Risks in Financial Market Development: The Role of Sequencing," IMF Working Paper 03/116 (Washington: International Monetary Fund).

Khan, Mohsin, 2003, "Current Issues in the Design and Conduct of Monetary Policy," IMF Working Paper 03/56 (Washington: International Monetary Fund).

Kokoszczynski, Ryszard, 2001, "From Fixed to Floating: Other Country Experiences: The Case of Poland," paper presented during the IMF High Level Seminar on Exchange Rate Regimes: Hard Peg or Free Floating? IMF, March 19-20, 2001.

Kongsamut, P., 2001, “Philippines: Preparations for Inflation Targeting,” IMF Working Paper 01/99 (Washington: International Monetary Fund).

Kovanen, Arto, 1996, "Establishing an Interbank Foreign Exchange Market: Institutional and Operational Modalities," Operational Paper 96/02 (Washington: International Monetary Fund, Monetary and Financial Systems Department).

Lau, Lawrence, 2003, "Is China Playing By the Rules? Free Trade, Fair Trade, and WTO Compliance," statement at a Hearing of the Congressional-Executive Commission on China, September 2003.

Leiderman, L., and G. Bufman, 1999, "Inflation Targeting Under a Crawling Band Exchange Rate Regime: Lessons from Israel," in Inflation Targeting in Practice: Strategic and Operational Issues and Application to Emerging Market Economies (Washington: International Monetary Fund).

Lindgren, Carl-Johan, Gillian G.H. Garcia, and Mathew Saal, 1996, Bank Soundness and Macroeconomic Policy (Washington: International Monetary Fund).

Minella, Andre, Paulo Springer de Freitas, Ilan Goldfajn, and Marcelo Kfoury Muinhos, 2003, "Inflation Targeting in Brazil: Constructing Credibility under Exchange Rate Volatility," Banco Central do Brasil Working Paper Series, No. 77 (Brasilia: Banco Central do Brasil).

Mishkin, Frederic, 2003, “Inflation Targeting in Emerging Market Economies,” NBER Working Paper Series No. 7618 (Cambridge, Massachusetts: National Bureau of Economic Research).

Morande, Felipe, 2001a, “A Decade of Inflation Targeting in Chile: Developments, Lessons, Challenges," Central Bank of Chile Working Paper (Santiago). 
— 2001b, "Exchange Rate Policy in Chile: Recent Experience," paper presented at the conference "Exchange Rate Regimes: Hard Peg or Free Floating?" IMF Institute, Washington, D.C., March 19-20, 2001.

Quirk, Peter, Graham Hacche, Viktor Schoofs, and Lothar Weniger, 1988, Policies for Developing Forward Foreign Exchange Markets, IMF Occasional Paper No. 60, (Washington: International Monetary Fund).

Rankin, Bob, 2001, “The Exchange Rate and the Reserve Bank's Role in the Foreign Exchange Market," (Sydney: Reserve Bank of Australia), available on the web at http://www.rba.gov.au/Education/exchange rate.html

Reserve Bank of New Zealand, 2004a, "Letter to Dr. Cullen on foreign exchange market intervention policy under section 16 of the Reserve Bank of New Zealand Act 1989" (Wellington: Reserve Bank of New Zealand), available on the web at http://www.rbnz.govt.nz/foreignreserves/intervention.

— $2004 b$, "Foreign Exchange Intervention Options" (Wellington: Reserve Bank of New Zealand), available at the web at http://www.rbnz.govt.nz/foreignreserves/intervention.

Rogoff, Kenneth, 1999, "Perspectives on Exchange Rate Volatility," in International Capital Flows (Chicago: University of Chicago Press).

—- Aasim M. Husain, Ashoka Mody, Robin J. Brooks, and Nienke Oomes, 2003, "Evolution and Performance of Exchange Rate Regimes," IMF Working Paper 03/243 (Washington: International Monetary Fund).

Sarr, Abdourahmane, and Tonny Lybek, 2002, "Measuring Liquidity in Financial Markets," IMF Working Paper 02/232 (Washington: International Monetary Fund).

Schmidt-Hebbel, Klaus, and Alejandro Werner, 2002, "Inflation Targeting in Brazil, Chile and Mexico," Central Bank of Chile Working Paper, No. 171 (Santiago).

Sveriges Riksbank, 2002, “The Riksbank's Interventions in the Foreign Exchange MarketOperations, Decision-Making and Communication” (Stockholm: Sveriges Riksbank).

Varhegyi, Eva, 2001, “Hungary’s Experience in the Crawling Peg Regime: Benefits and Costs," paper presented during the IMF High Level Seminar on Exchange Rate Regimes: Hard Peg or Free Floating?, IMF, Washington, D.C., March 19-20, 2001.

Williamson, John, 1996, The Crawling Band as an Exchange Rate Regime: Lessons from Chile, Colombia, and Israel (Washington: Institute for International Economics). 